\title{
الروية الإبداعية للفنون الرقمية التجريدية والإفادة هنها في صياغات فنية لإثراء الجانب الزخرفي لأزياء المرأة المعاصرة
}

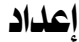 \\ ه. وفاء محمد محمد سما حة \\ أستاذ مساعد النسيج والملابس - جامعة المنصورة \\ أستاذ مساعد النسيج والملابس - جامعة الملك خالد
}

مجلة بحوث التربية النوعية ـ جامعة المنصورة

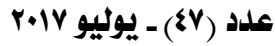


בب الرؤية الإبباعية للفنون الرقمية التجريدية والإفادة منها ِِ صياغات فنية لإخراء الجانب الزخرفى لأزياء المراة المعاصرة لـ 


\title{
الرؤية الإبداعية لافنيون الرقمية التجريدية والإفادة هنها
}

\section{في صياغات فنية لإثراء البانب الزخرفي لأزياء المرأة المعاصرة}

\author{
إعداد \\ * . وفـاء محمد محمد سماحة
}

unil|

لقد أصبحت التقنيات الرقمية بهثابة لغة العصر حيث يته إدخال المنظومات الرقمية

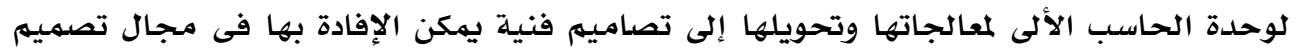

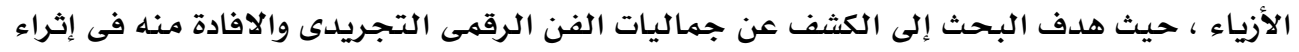

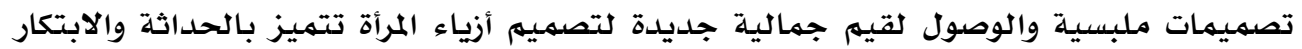

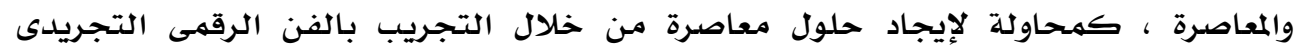

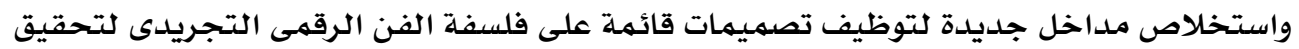

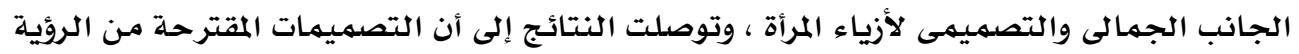

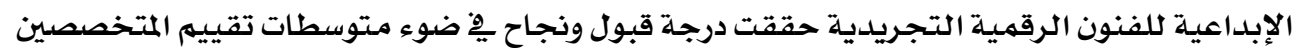

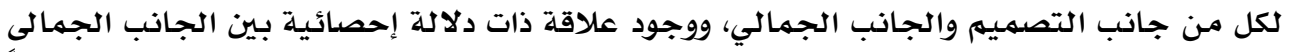

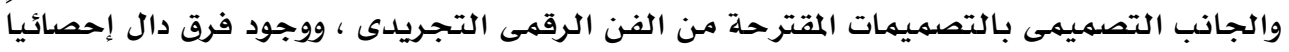

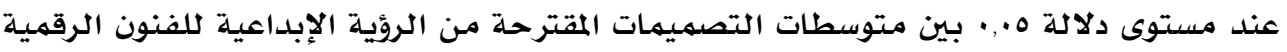

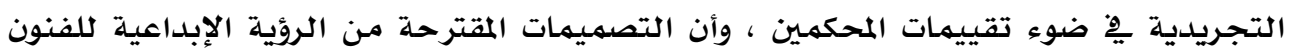

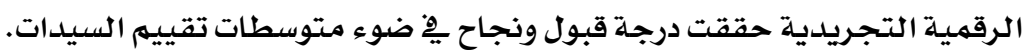

الإقدمية:

تُعد التكنولوجيا التى صنعها العقل البشرى التحدى المطلق ليس فقط فى مجال العلوم

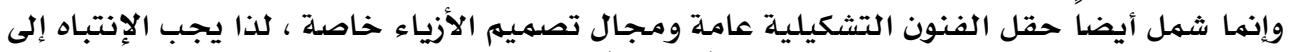

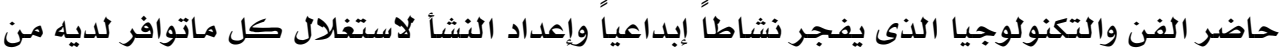

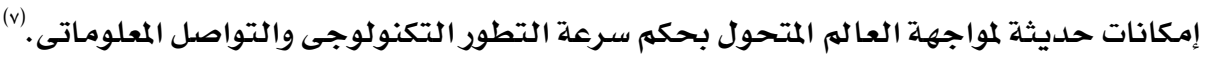

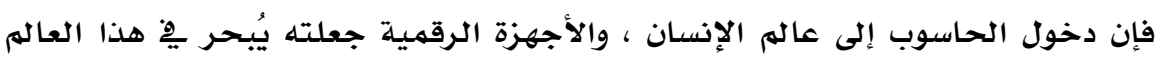

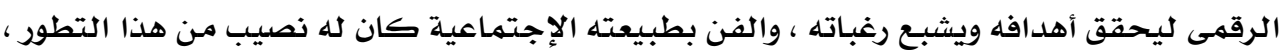

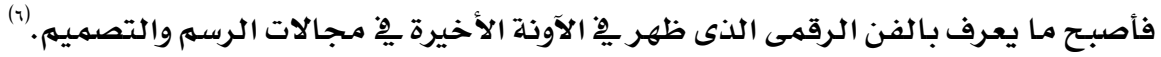

" أستاذ مساعد النسيج والملابس - جامعة المنصورة و أستاذ مساعد النسيج والملابس - جامعة الملك خالد 
ولقد ساهمت التطورات المستمرة للتكنولوجيا الرقمية المضغوطة (Impact) مِِّ التطوير

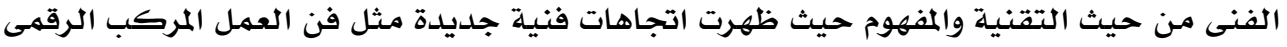
(Digital installation art)

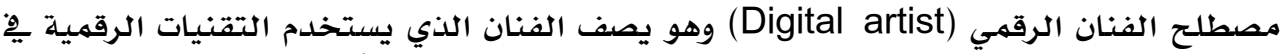

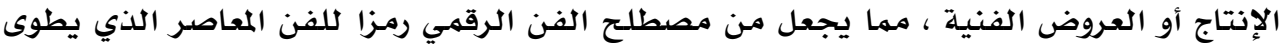

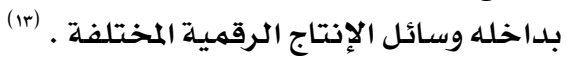
إن توسـع الشبكة العنكبوتية على وجه خاص كان لـه إسهام كبير يِّ انتشار الفنون الرقمية

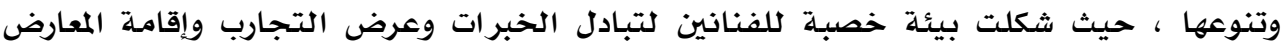
الإلكترونية.

وتصميم الأزياء يرتبط بعلاقة وثيقة باتجاهات الفن الحديث لما يحويه من قيه جمالية

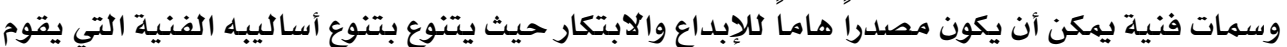

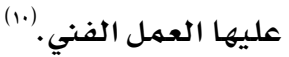
وأنه باستطاعه الفنان صاحب الموهبة ولديه المعرفة باستخدامات الحاسب الآلى والبر امجج

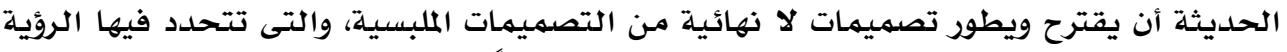

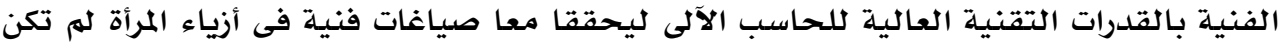
لتتحقق بدون توافر هذه التكنولوجيا.

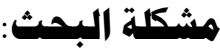
تتحدد مشكلة البحث يِّ الإجابة على التساؤل الآتى : هل يمكن الإفادة من الرؤية الإبداعية للفنون الرقمية التجريدية فى صياغات فنية لإثراء

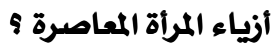

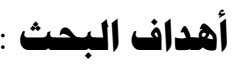
ا. مُحاولة إيجاد حلول جديدة من خلال التجريب بالفن الرقمى التجريدى لإبراز الجانب الجمالى لأزياء معاصرة المرأة.

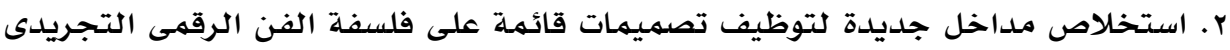
لتحقيق الجانب الجمالى والتصميمى لأزياء المرأة. r. الكثف عن جماليات الفن الرقمى التجريدى والافادة منه فى إثراء تصميمات ملبسيسية معاصرة. ع. الوصول لقيه جمالية جديدة لتصميم أزياء المرأة تتميز بالحداثة والابتكاروالمعاصرة.

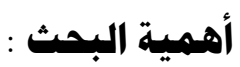
ا ـ يُسهـمه هِّ إلقاء الضوء على امكانيات الفن الرقمى التجريدى فى استحداث تصميمات مبتكرة. 
مجلة بحوث التربية النوعية - علدد

r. الاهتمام بتكوين رؤية جديدة حول توظيف الفن الرقمى التجريدى ِِّ صياغات تصميمـة ملبسية معاصرة بأسلوب الطباعة على الأقمشة جلئ.

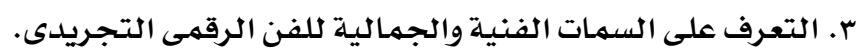

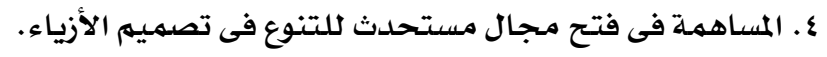

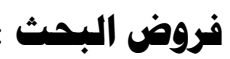

ا.تُحقق التصميمات المقترحة من الرؤية الإبداعية للفنون الرقمية التجريدية درجة قبول

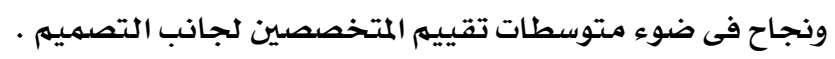

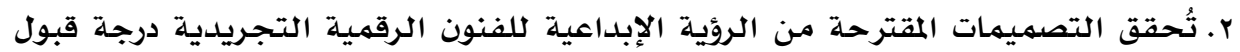

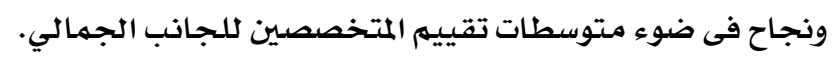

r. تُوجد علاقة ذات دلالة إحصائية بين الجانب الجمالى والجانب التصميمى بالتصميمات

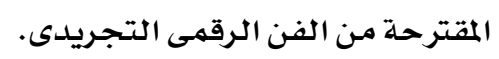

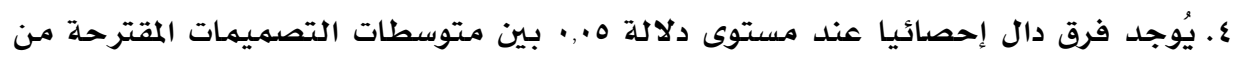

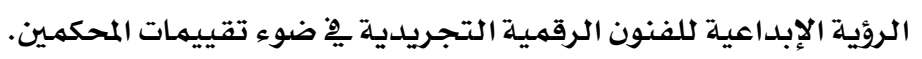

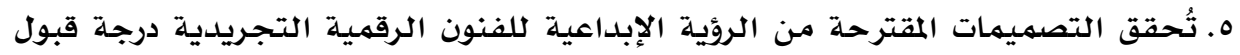

$$
\text { ونجاح فى ضوء متوسطات تقييم السيدات. }
$$

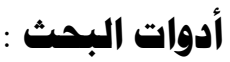

1. تصميمات من ( الفن الرقهى التجريدى - أزياء المرأة (موديلات لعارضات أزياء جاهزة )).

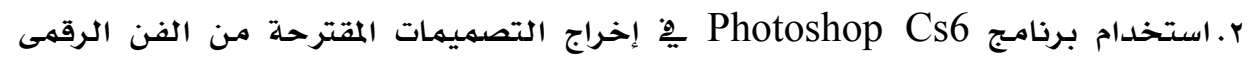

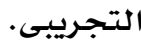

r. إستمارتى إستبيان لتحكيم التصميمات المقترحة ( من إعداد الباحثة).

هدود البحث:

1. حدود بشرية : عينة عشوائية قوامها (1 ـ 1) سيدة عاملة يتراوح أعمارهن من 0ب: هبعام

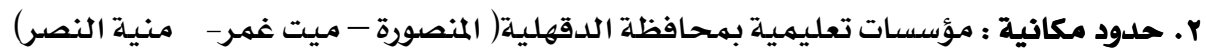

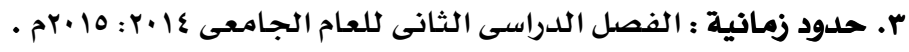

\section{هنهمج البحث:}

المنهج الوصفي : دراسـة تحليلية لجماليات الفن الرقمى التجريدى.

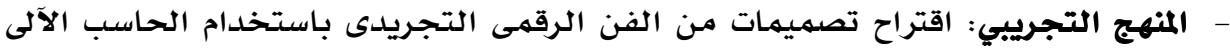

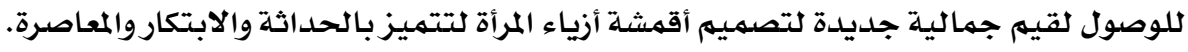




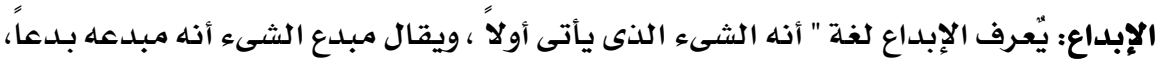

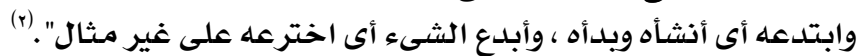

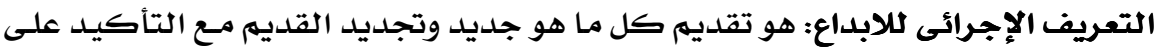

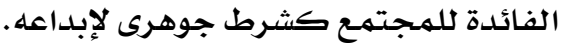

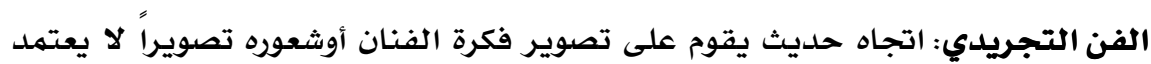

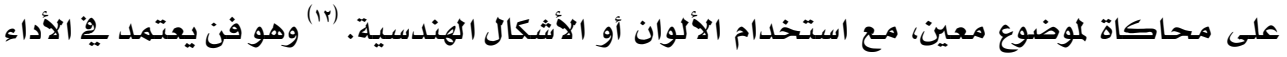

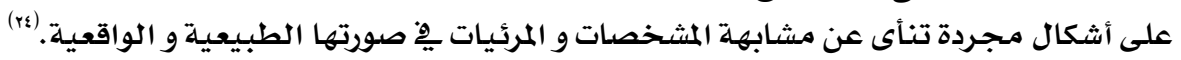

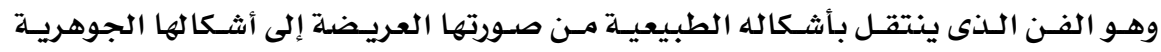

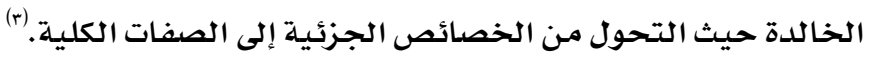

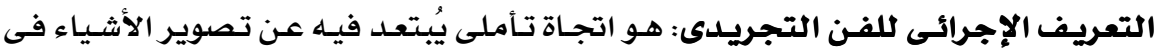

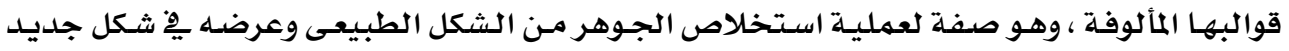

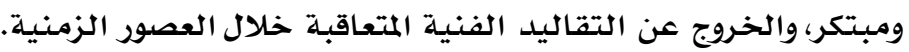

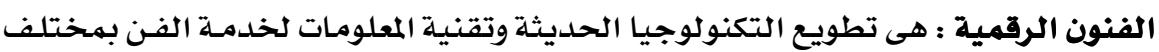

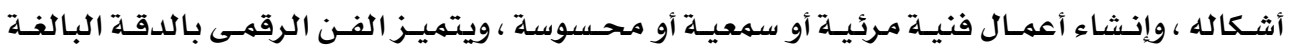

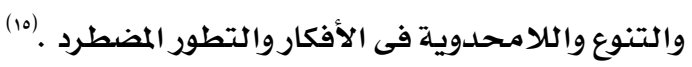

التعريـف الإجرائـى للفـن الرقمـي : التعبير عن التصميمات الفنيـة بواسطة التكنولوجيـا

الرقمية عن طريق الحاسب الآلى وبرامج الملتيميديا (Multimedia Programs).

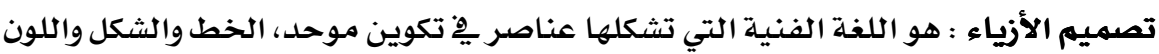

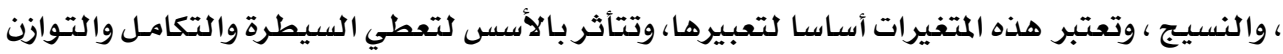

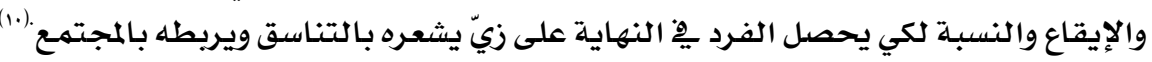

\section{الدراسات السابقة :}

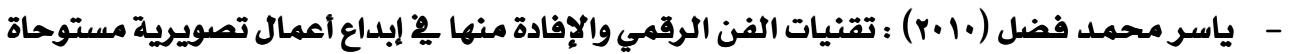

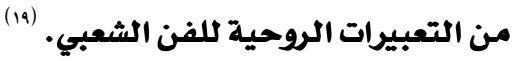

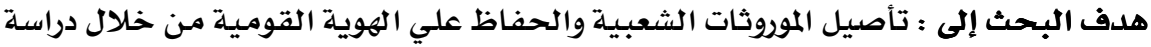

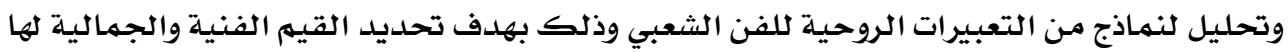

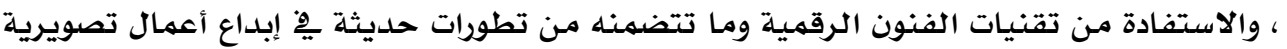

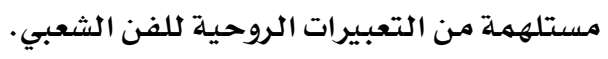




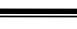

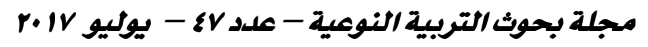

وتوصلت النتائج إلى: أنه ساعدت دراسـة القيم الفنية والجمالية للتعبيرات الروحية للفن

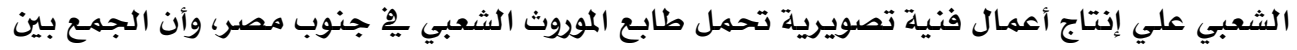

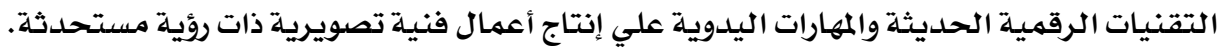

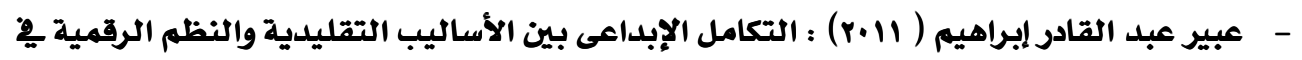

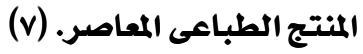

هدف البحث إلى :الإفادة من التكامل الإبداعى بين التقنيات التقليدية والنظم الرقمية

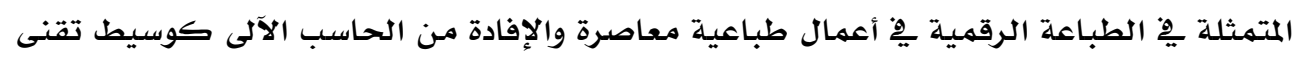
لإيجاد منطلقات جديدة وصياغات تثرى العمل الطباعى .

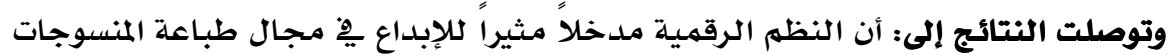

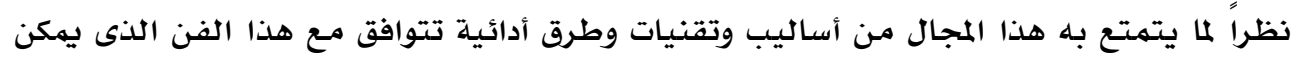

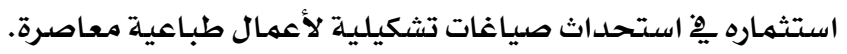
- مروة ممدوح مصطفى حمود (r. r) : التكامل الإبداعى بين أساليب النظم الرقمية الحديثة

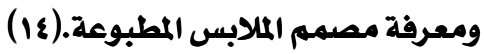

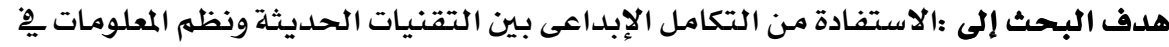

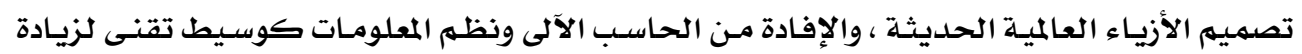

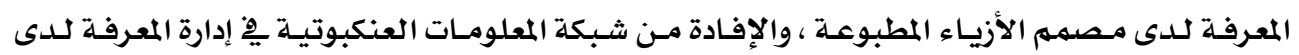

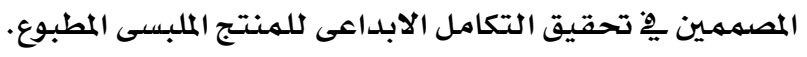

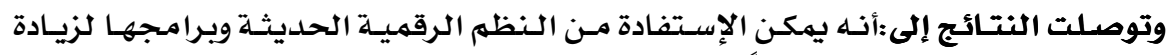

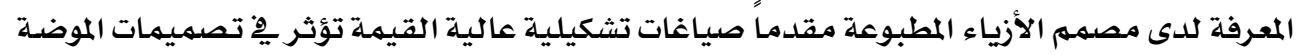

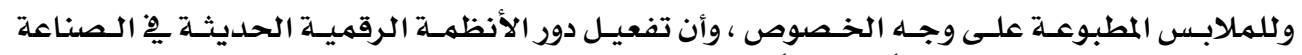

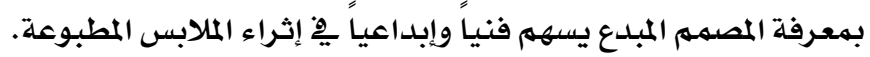
- أحمد أبو بكر الهادي (عا+r) :الفنون الرقمية " دراسة تحليلية للواقع الافتراضي واساليب

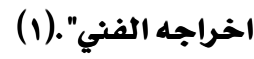

هدفت الدراسة إلى : استنبـاط أسس لتطوير مفـاهيم جماليـات الواقـع الإفتراضـي وتحديـ

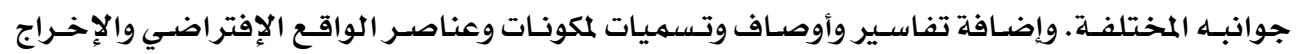

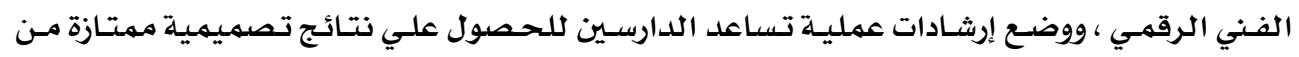

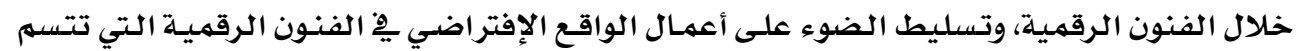
بالأصالة والتميز محلياً وداخلياً.

وتوصلت النتائج إلى: أهمية التزام جماليات الواقع الإفتراضي بالأسس الجمالية التقليدية

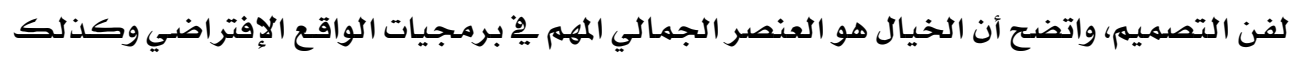


בب الرؤية الإبباعية للفنون الرقمية التجريدية والإفادة منها ِِ صياغات فنية لإخراء الجانب الزخرفى لأزياء المراة المعاصرة لـ

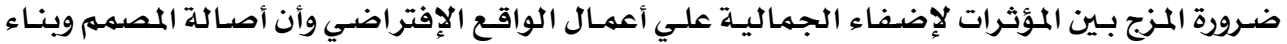

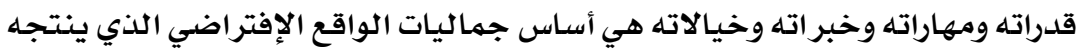

\section{تعليق عام على الدراسات السابقة :}

بعد الاطلاع على الدراسات السابقة والمرتبطة بموضوع البحث اتضح الآتى:

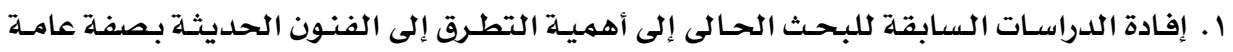

والنظم الرقمية بصفة خاصدة.

r. إتفـاق الدراسـات السـابقة مـع البـحث الحـالى فى توظيـف التقنيـات التكنولوجيـة فى مجـال

الملابس.

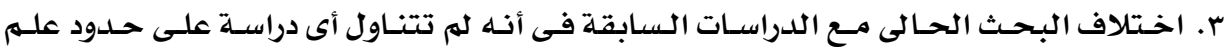

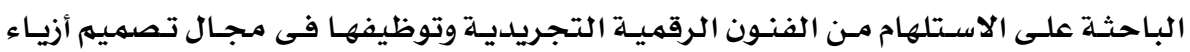

المرأة.

\section{الإطار النظري :}

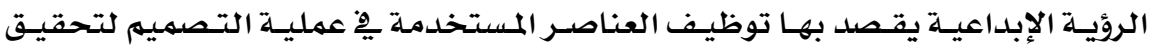

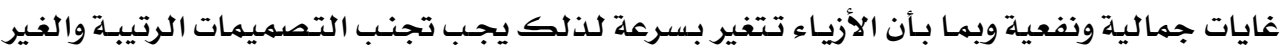

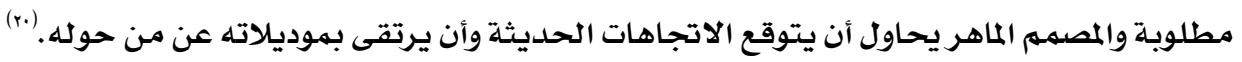

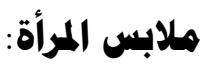

تتميز أزياء المرأة بموديالات وتصميمات تتسهم بالجمال ويهكن أن تتأثر أطوالها تبعاً تبعاً للتغيرات

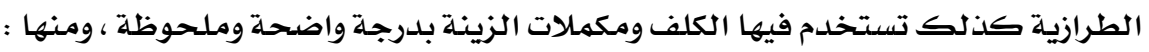

ا ـ ملابس الحفلات الرسمية ، وأكثر الفساتين التي ترتدى خلال هذه الحفلات هى ذات اللون

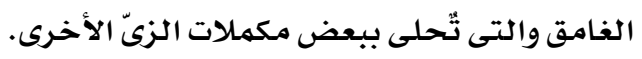

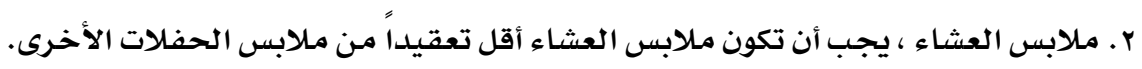

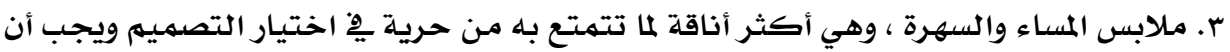

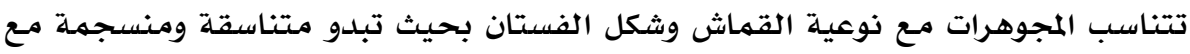

$$
\text { الثوب. (11) }
$$

\section{التصميم الزخرفي Decorative Design}

هو ترجمة لموضوع معين بفكرة مرسومـه هادفة لها علاقة بوسيلة التنفيذ وتحمل قيماً فنيـة

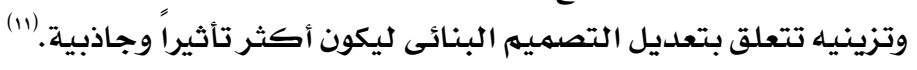

والتصميهم الزخرفى هو الإضافة التي تعطي العمل الفني الطـابع الخـاص بـه والذي يميـزه

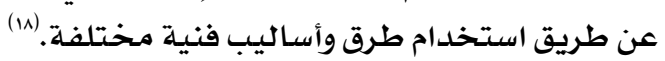




\section{أهمية التصميم الزخرفى :}

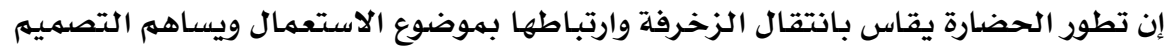

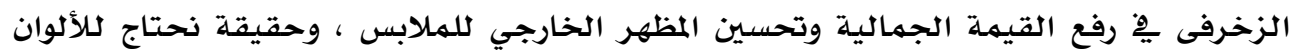

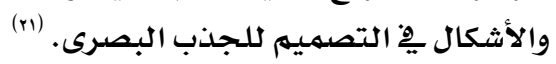

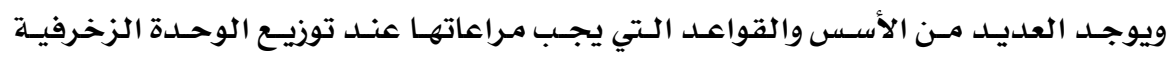

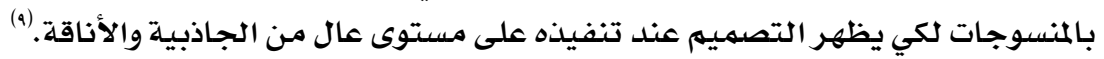

\section{من أهم قواعد نجاح التصميم الزخرفى:}

• توزيـع الوحدات وتنسيقها يِّ اتزان وتنسيق وريط الألوان يِّ علاقات مدروسة.

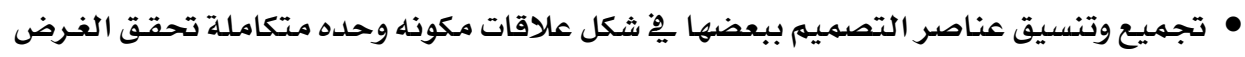

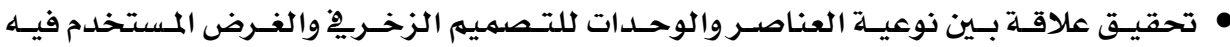

التصميه.

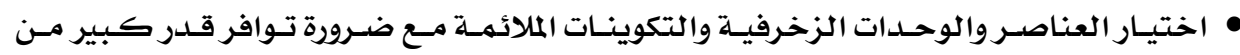

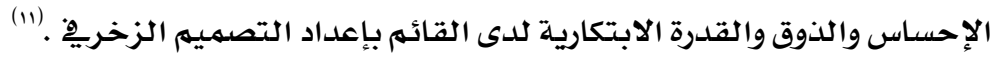

التبريد في الفن :

لفظ التجريد ِِّ الفن التشكيلى المعاصر هو صفة لعملية استخلاص الجوهر من الشكل

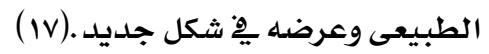

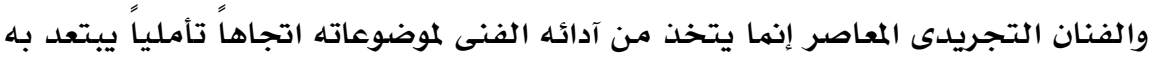

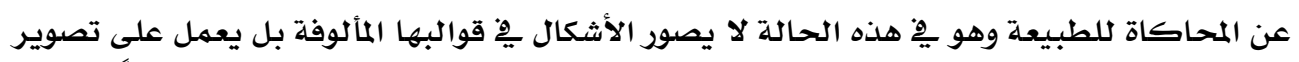

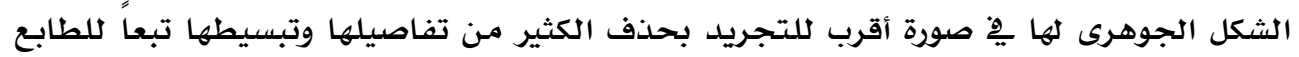

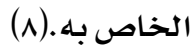

وسواء كان التجريد هندسيا شاملاً أو جزئياً بتبسيط الأقواس والمنحنيات أى تجريداً

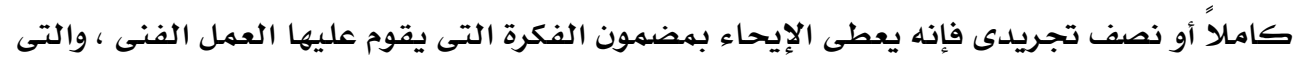

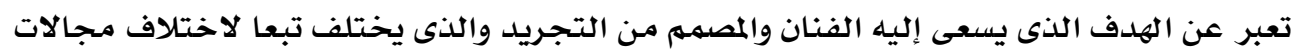
(ra). إستخدامن العداف

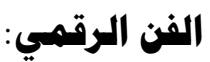

ليس إلا مزيجا من التكنولوجيا والإبداع يتجسد مِّ تغيير ثقافة التعبير ويعطي عصرًا

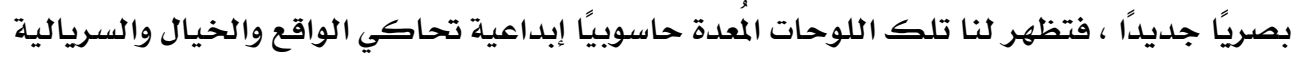

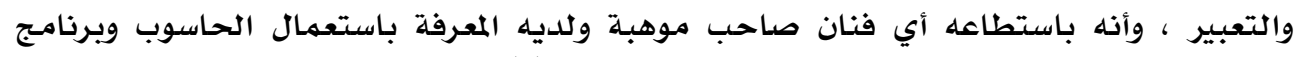

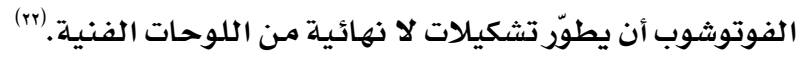


فنانو الفز الرقمى منهم :

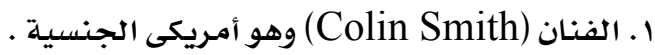

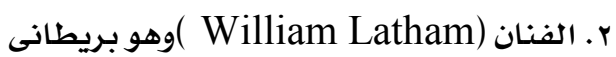

أهمية استخدام الحاسب الآلى في التصميم الرقمى :

• • مانخفاض التكلفة المادية .

• سـهولة إضـافة التـاثيرات ( تعسديل - تكبير - تصغير- إمانـة - قلسب - انعكـاس ) دون إعـادة

$$
\text { للرسم الأساسى. }
$$

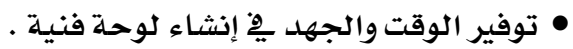

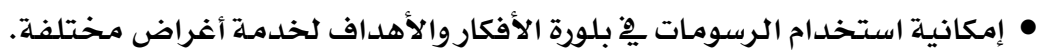

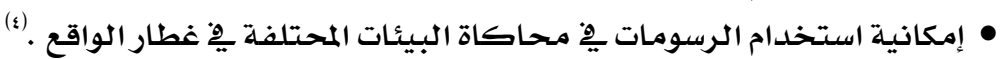

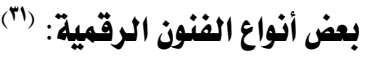

الفن التجريدي Abstract Art

وهو يتصف بالخروج عن الطبيعة بتداخلات لونية وشكلية بشكل عشوائي. قد لا يكون

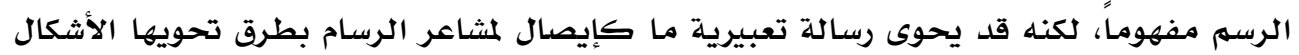

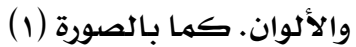

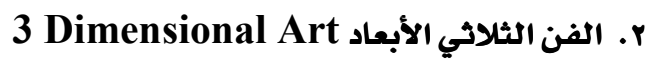

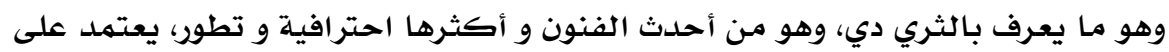

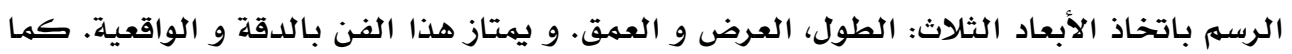

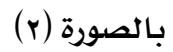

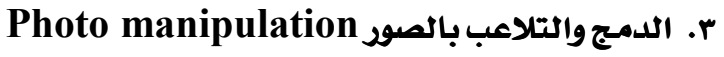

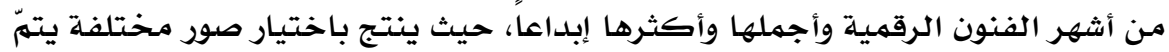

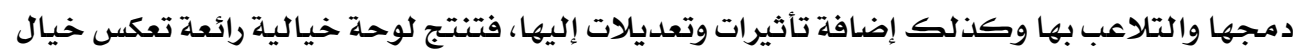

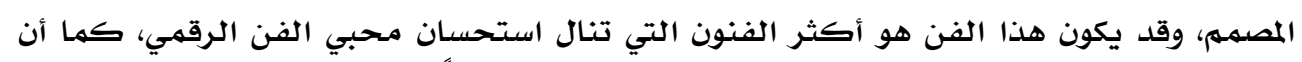

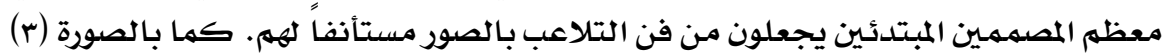

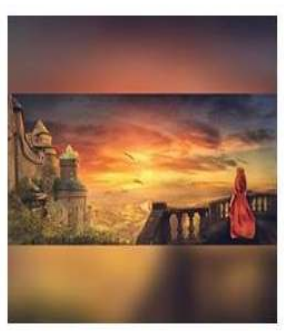

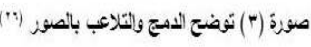

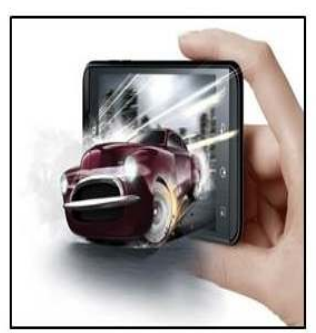

صوزة (†) توضح الفن الثلاثني الأبعاد (")

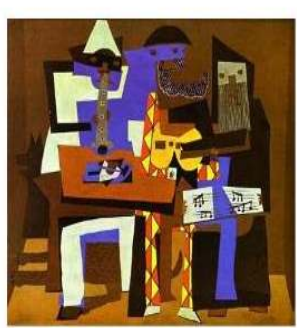

صنوز (1) توضح الفن التجريثي 


\section{بعض مز اتجاهات الفز الرقمى :}

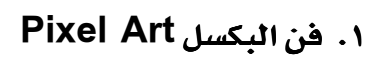

البكسل هي أصغر وحدة لمقاسات الصور، و فن البكسل هو أيضاً أحد الفنون التي تعتمد البـال

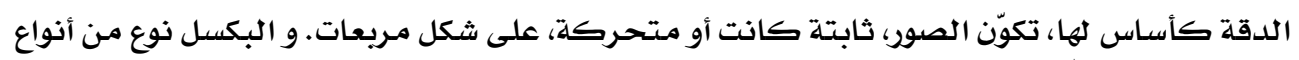

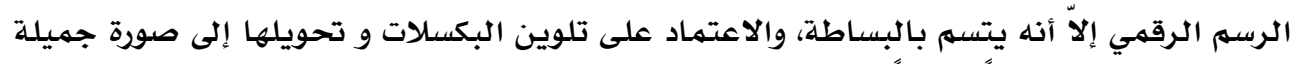

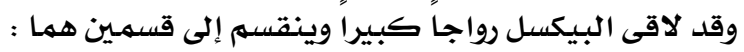
أ. متماثلة الأبعاد Isometric :وهى رسوم بسكيلية ثلاثية الأبعاد يتم رسمها دون استخدام

$$
\text { برامج }
$$

ب. غير متماثلة الأبعاد Non-isometric : وهى رسوم ثلاثية الأبعاد كرسهم شكل من الأمام

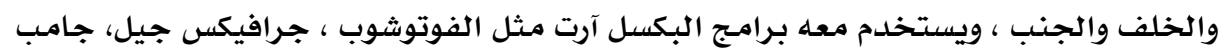

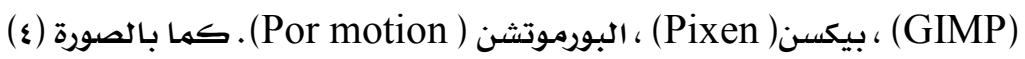

\section{Vector ب المتجهات}

هو فن مختص لعمل الزخارف والشعارات (اللوجو) واللوحات الإعلانية (البوستر) ويتميز

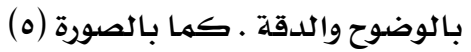

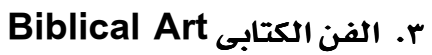

هو نوع قليل الإنتشار ِِّ أوساط التصميهم وهو يعتمد على الحرف كمنصر أساسى ويقوم

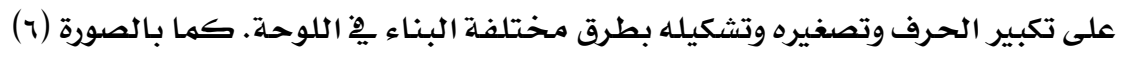

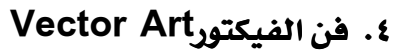

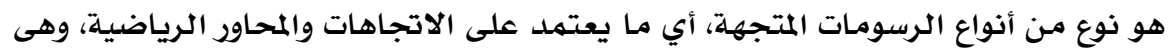

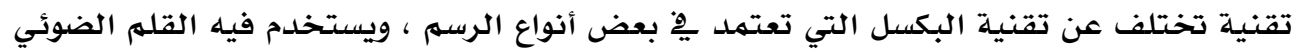

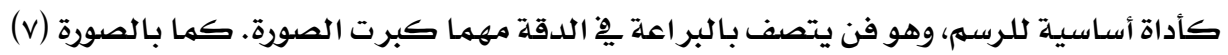
ه.

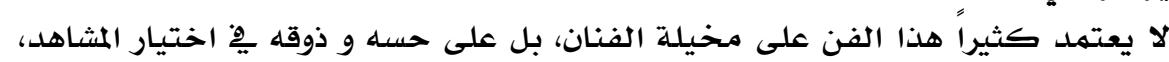

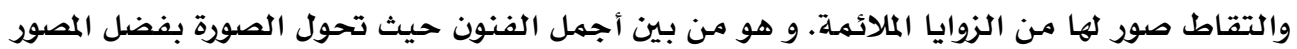

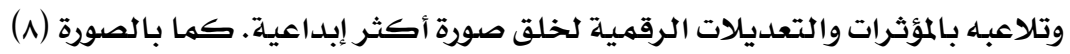




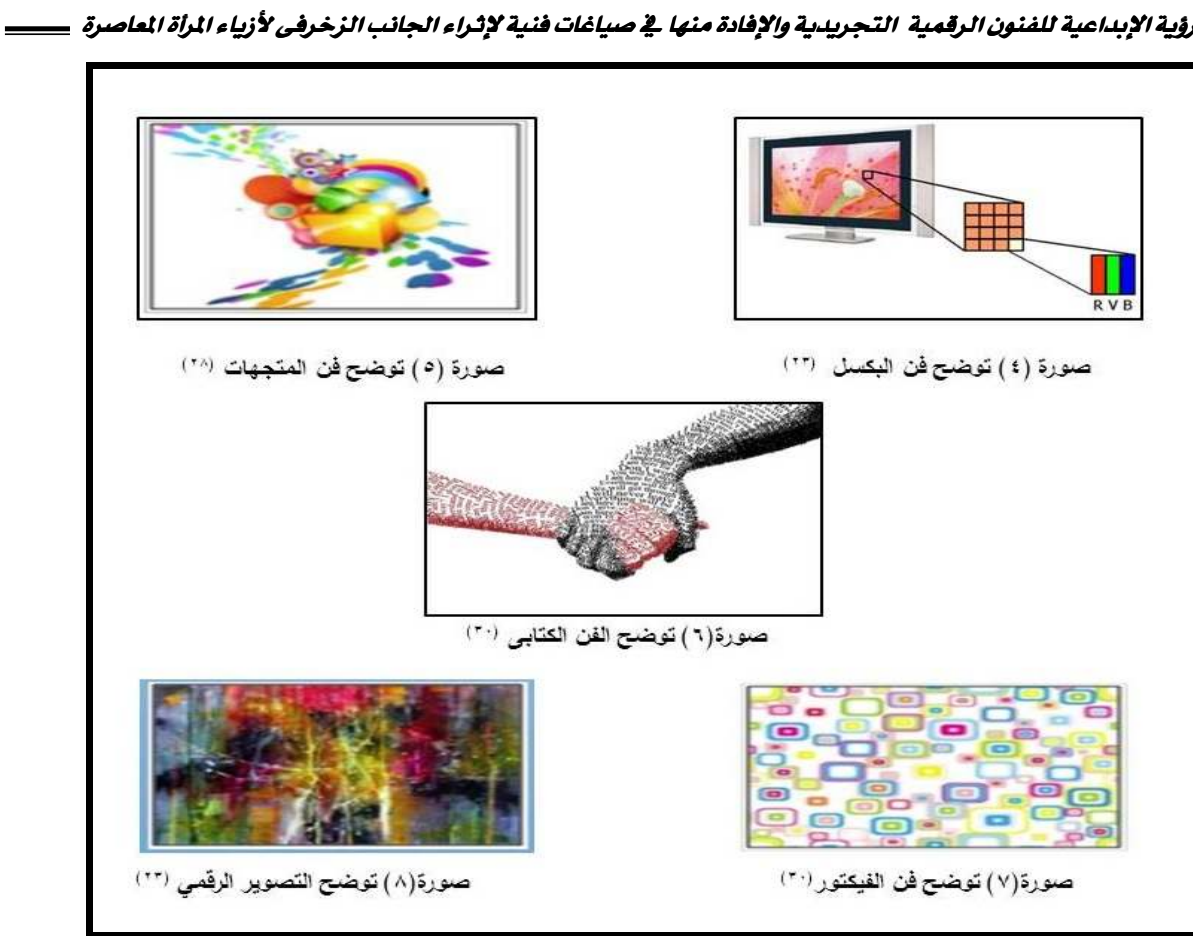

إجراءات البحث:

ا ـ تحديد خطوات التنفيذ والبدء فى تصميم عدد (•r) مقترح بالإقتباس من الفن التجريدى إسى

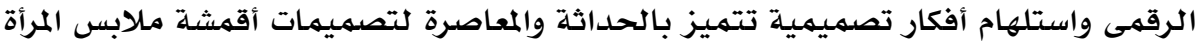

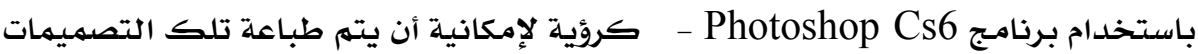

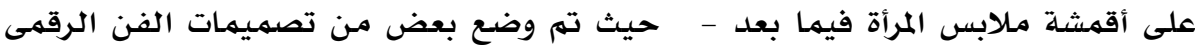

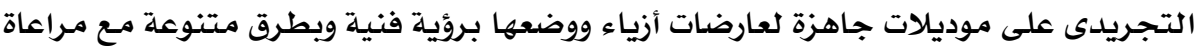
تناسق الألوان وعناصر وأسس التصميه وذلك موديلك في واجهة الموديل ( الأمام) .

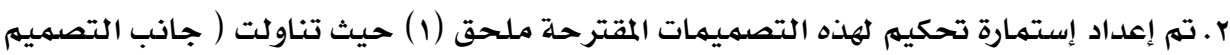

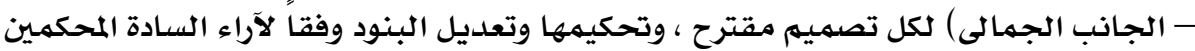

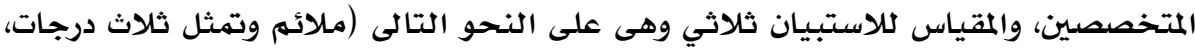

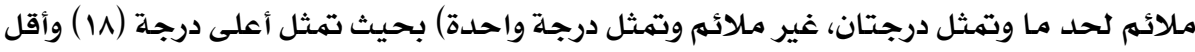

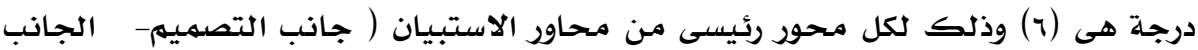

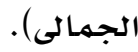

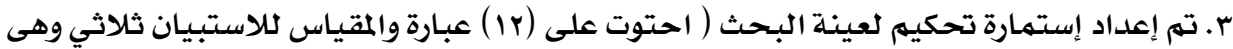

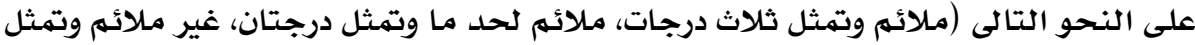

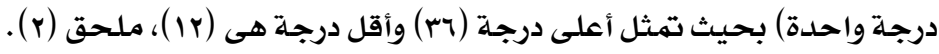


مجلة بحوث التربية النوعية - علدد

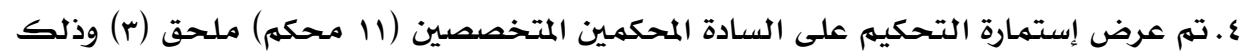

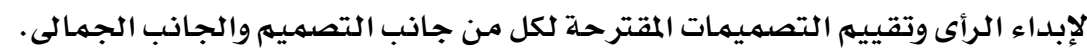

ه. تم عرض إستمارة التقييهم على عينة البحث (1. 1) وذلك لإبداء الرأى للتصميمات المقترحة

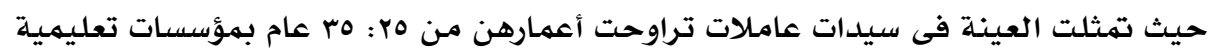

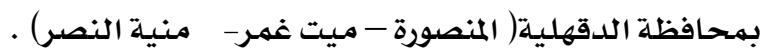
7. تم استخدام أسلوب التحليل الإحصائى المناسب لمناقشة الفروض والنتائج . التصميسمات المترحة
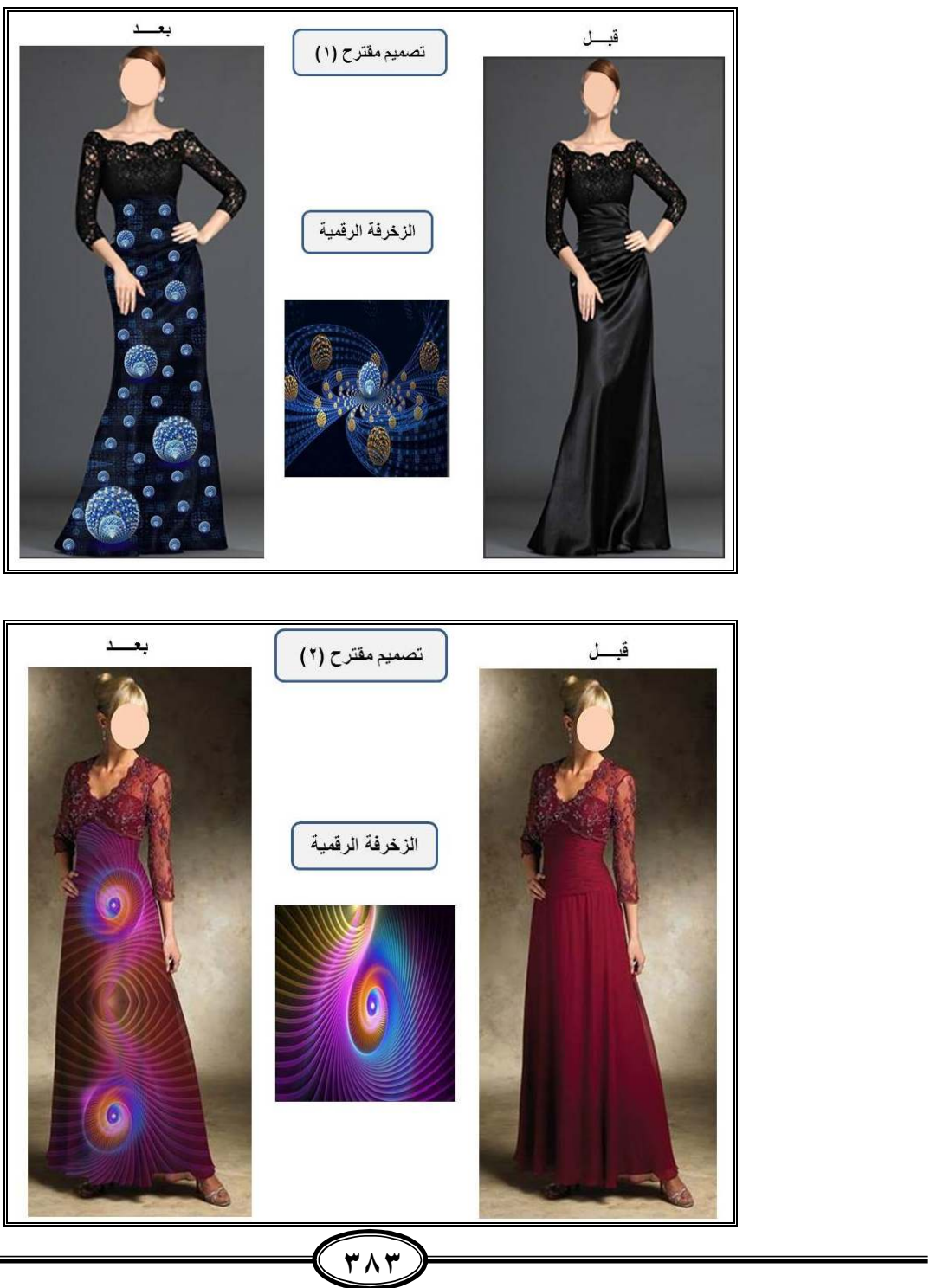


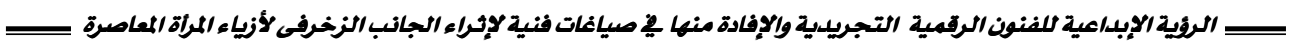
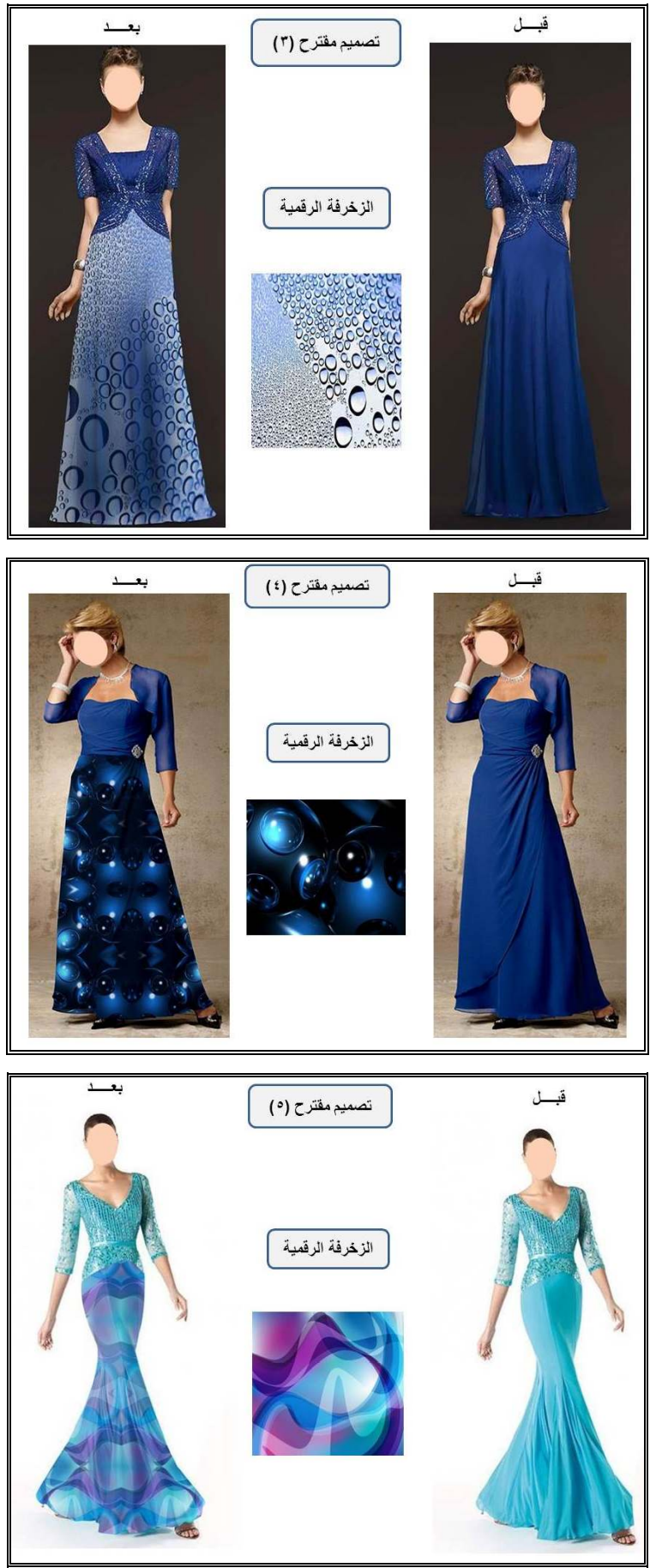

$r \wedge \varepsilon$ 
مجلة بحوث التربية النوعية - علدد
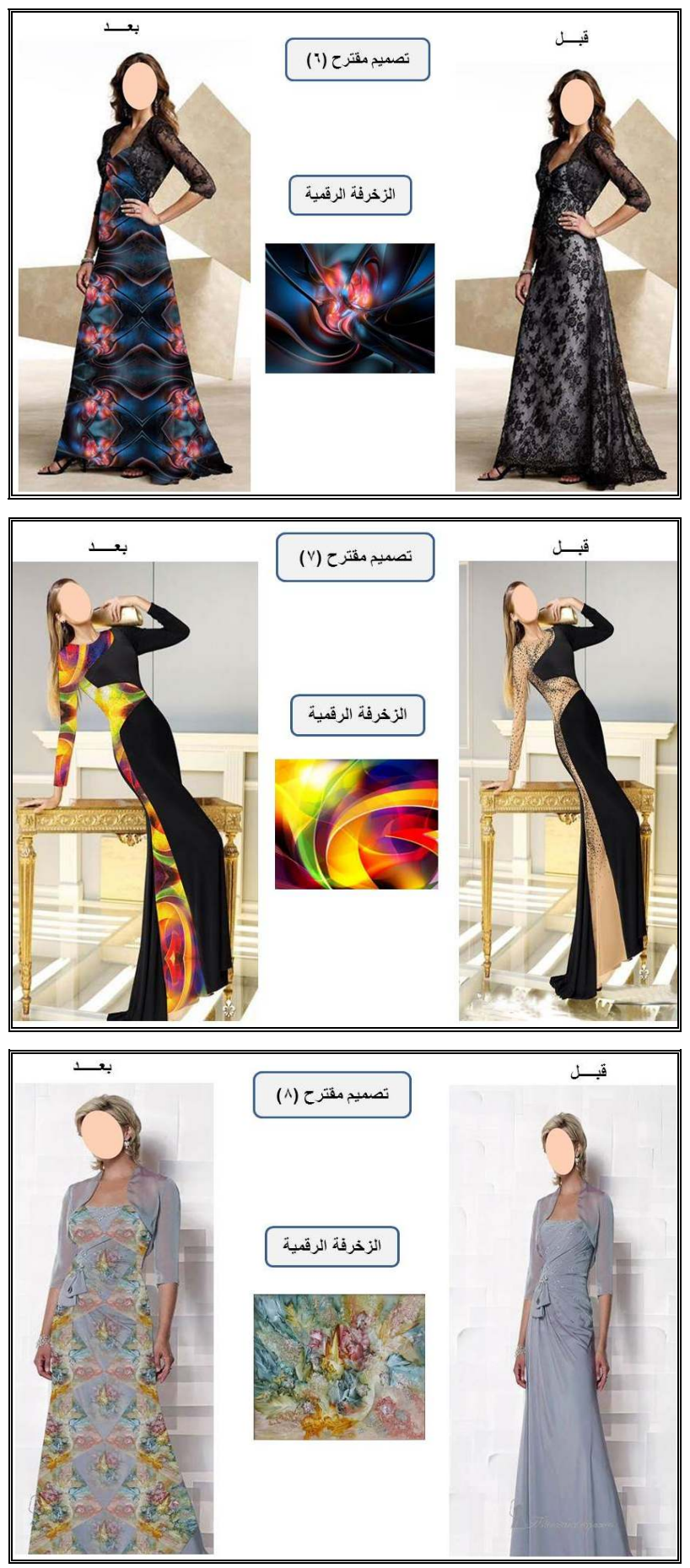

rᄉo 
בب الروية الإبداعية للفنون الرقمية التجريدية والإفادة منها ِِ صياغات فنية لإخراء الجانب الزخرفى لأزياء المراة المعاصرة لـ
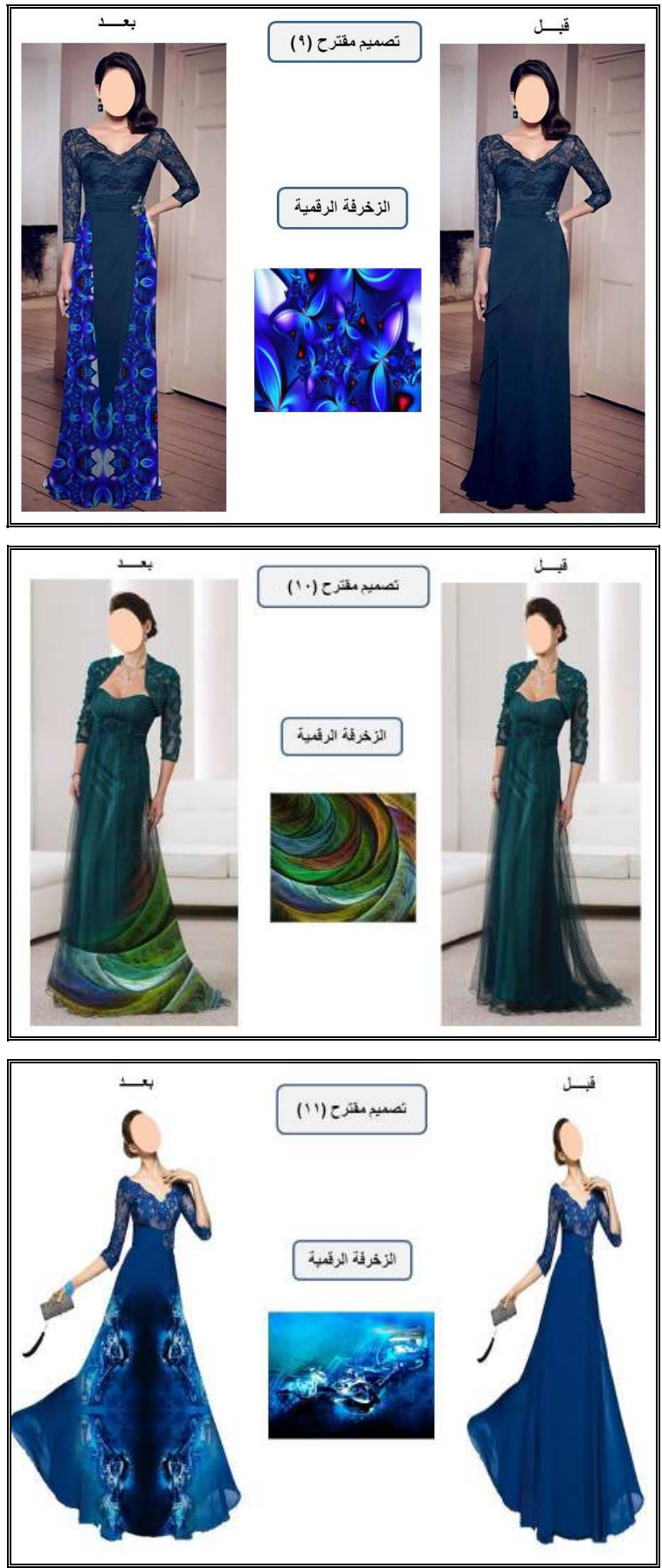
مجلة بحوث التربية النوعية - عدد VI - يوليو r.lV
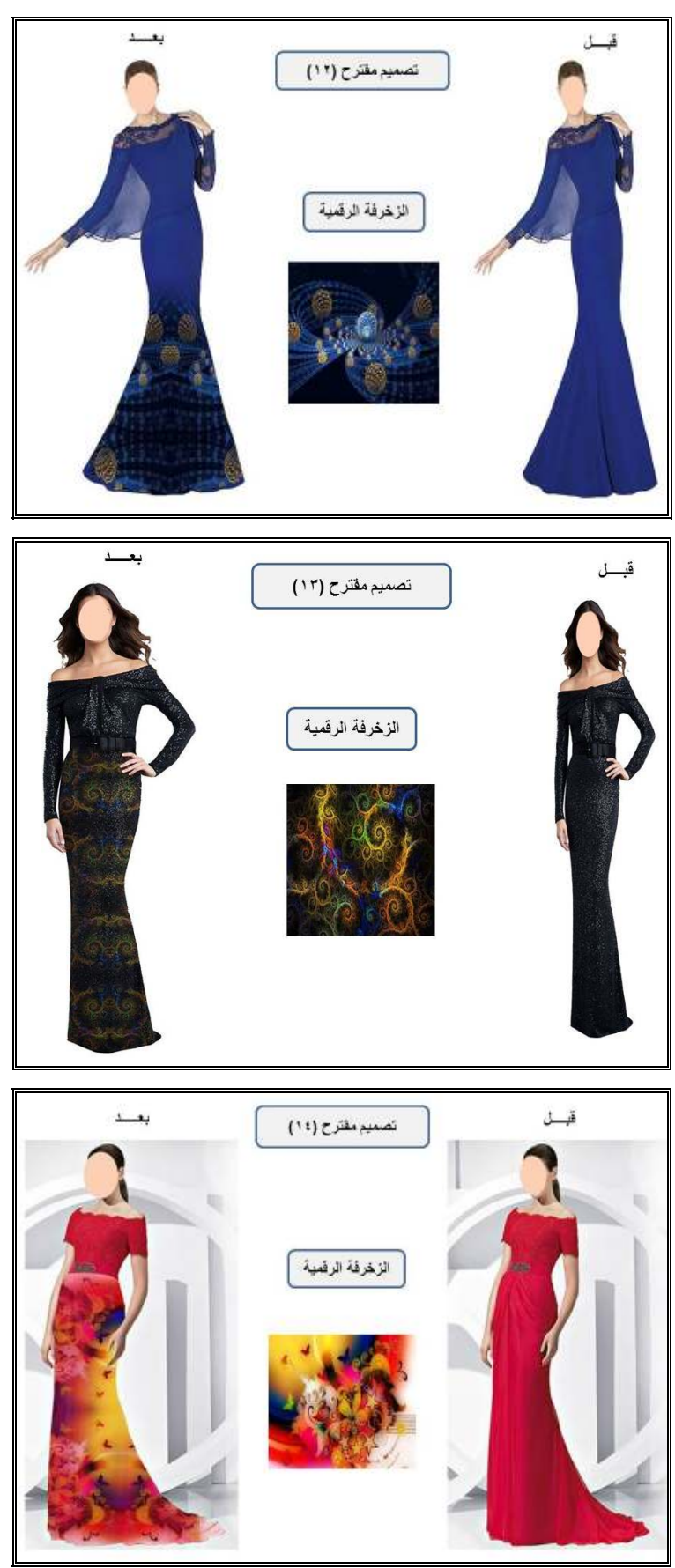
בب الرؤية الإبباعية للفنون الرقمية التجريدية والإفادة منها ِِ صياغات فنية لإخراء الجانب الزخرفى لأزياء المراة المعاصرة لـ
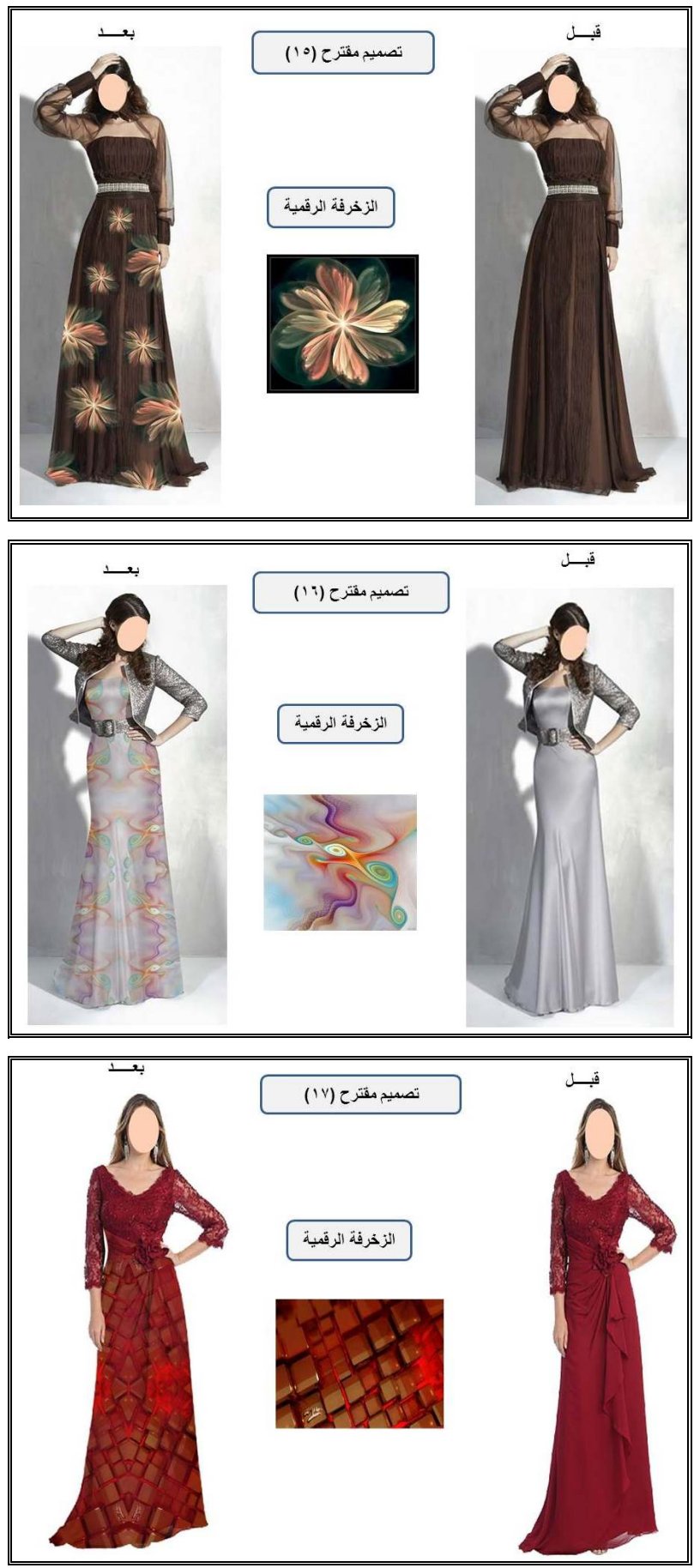
مجلة بحوث التربية النوعية - علدد
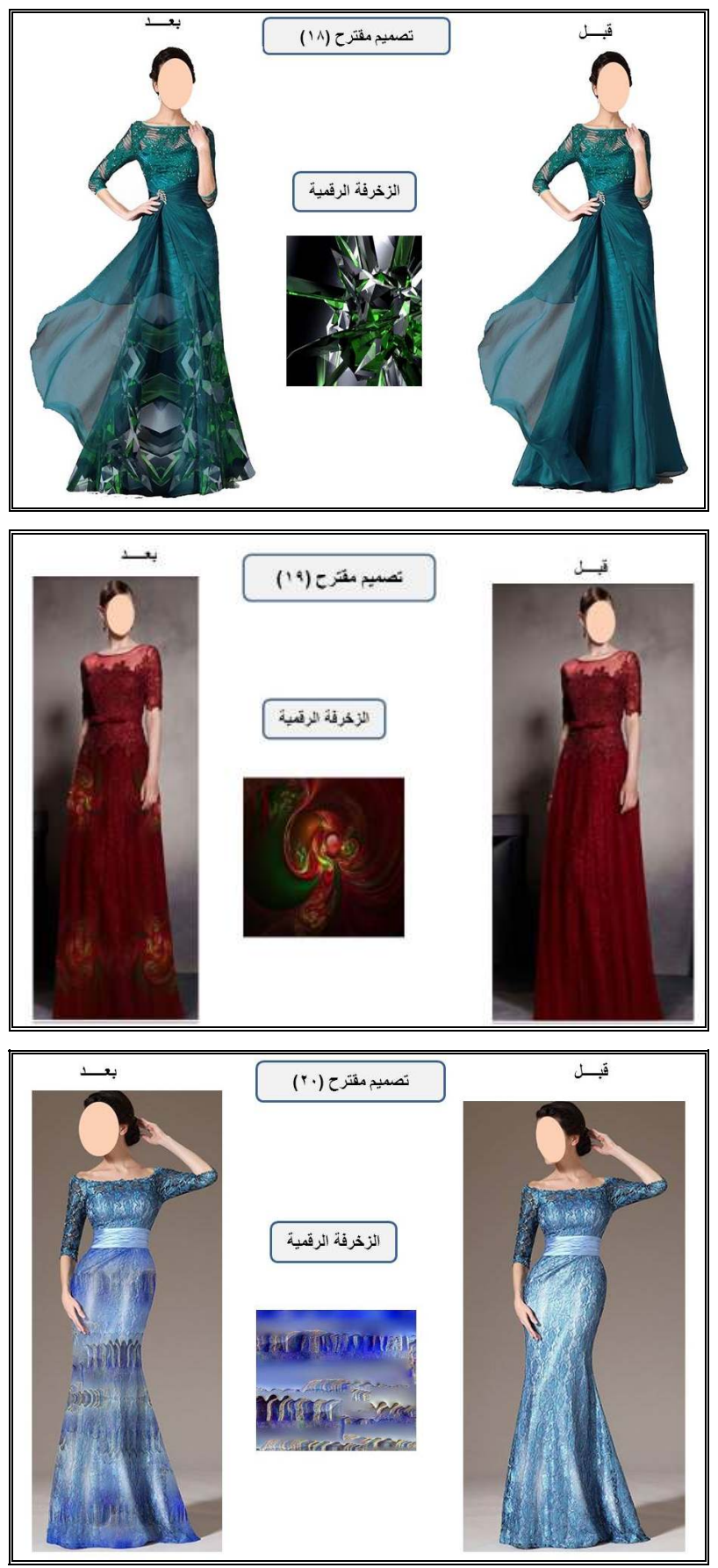
ا. استبيان حول رأي بعض خبراء التخصص في بطاقة تقييم التصميمات المقترحة من الرؤية الإبلداعيـة للفنـون الرقمية التجريلية. أولاً: اختبار صدق محتوى الاستبيان :

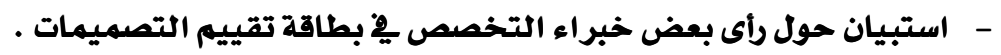

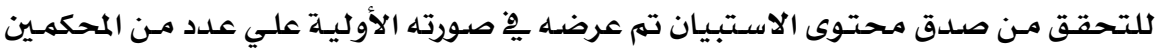

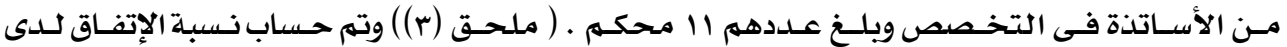
المحكمــين علي كل عبـارة مـن عبـارات الإستبيان، وتم استبعاد العبـارات التي تقل نسبة اتفـاق المحكمـين عليها

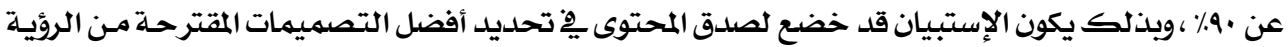
الإبداعية للفنون الرقمية التجريدية.

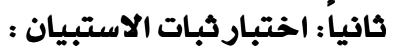

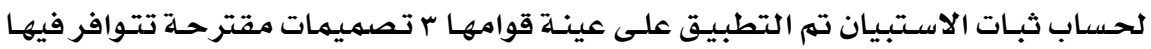

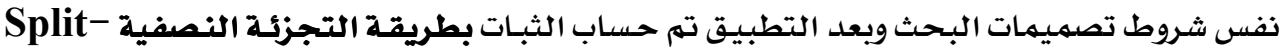
Half

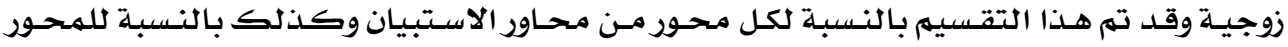

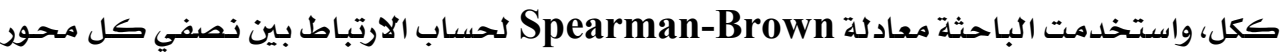

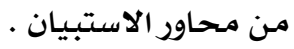

جدول (1) يوضح معامل ارتباط التجزئة النصفية لمحاور الاستبيان ككل ومحاوره الفرعية

\begin{tabular}{|c|c|}
\hline معامل ارتباط سيبرمان ـ براوذ & المحور \\
\hline •, qr & الأول: جانب التصميي \\
\hline •, qr & الثاني: الجانب الجمالي \\
\hline - 970 & المحاور ككل \\
\hline
\end{tabular}

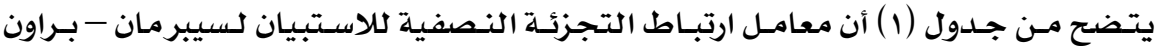

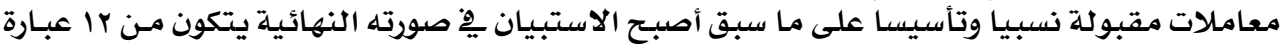

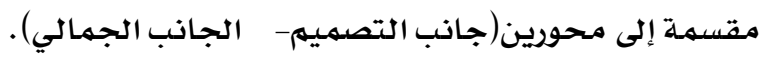

r. استبيان حول رأى السيدات فى التصميمات المقترحة من الرؤية الإبلداعية للفنوز الرقمية التجريدية. أولاً: اختبار صدق محتوى الاستمارة:

- استبيان حول رأى السيدات عينة البحث فِ بطاقة تقييم التصميمات المقترحة.

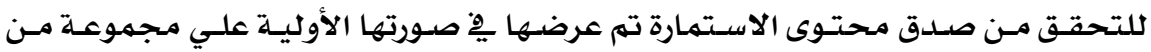

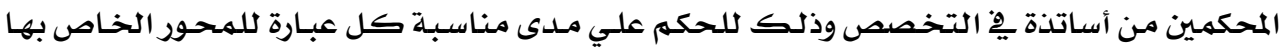

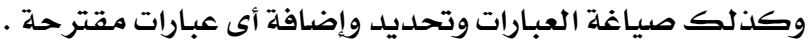


وتم حساب نسبة الاتفاق لدي المحكمين علي كل عبارة من عبارات الاستبيان ، وتم استبعاد

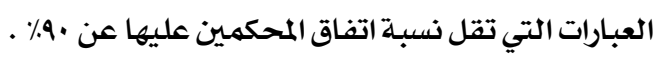

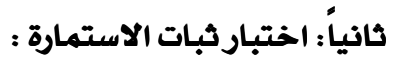

لحساب ثبات الاستمارة تم التطبيق على عينة قوامها ب تصميمات مقترحة تتوافر فيها

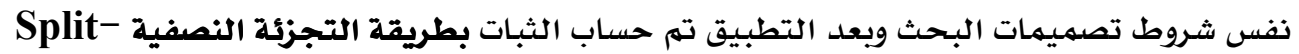
Half

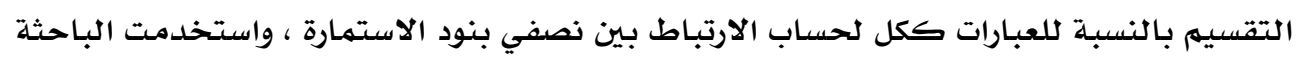

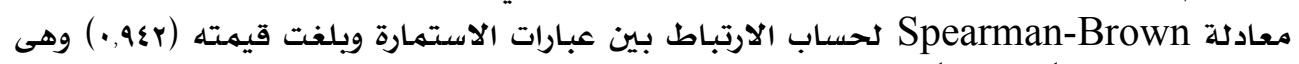

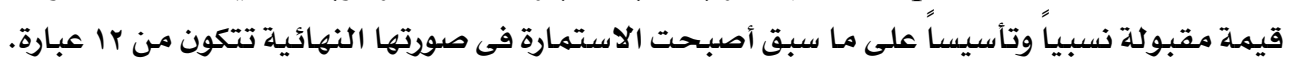

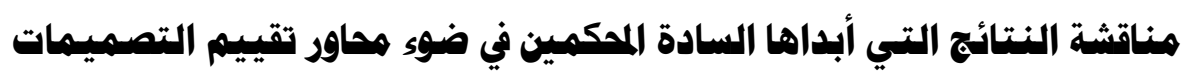
الفرض الأول:

تُحقق التصميمات المقترحة من الرؤية الإبداعية للفنون الرقمية التجريدية درجة قبول

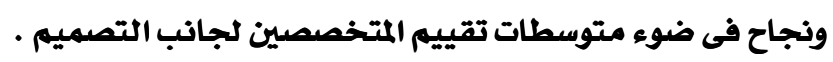
جلول (r) يوضح متوسطات تقييمات المتخصصين لحانب التصميم للتصميمات المقتر حة

\begin{tabular}{|c|c|c|c|c|c|c|c|c|c|c|c|c|c|c|c|c|c|c|c|c|}
\hline 20 & 19 & 18 & 17 & 16 & 15 & 14 & 13 & 12 & 11 & 10 & 9 & 8 & 7 & 6 & 5 & 4 & 3 & 2 & 1 & عبارة الاستبيان/ التصميم \\
\hline 2.6 & 2.6 & 3 & 2.9 & 3 & 2.9 & 2.9 & 2.9 & 2.8 & 2.6 & 2.7 & 2.9 & 2.8 & 2.9 & 2.9 & 2.4 & 2.4 & 2.6 & 2.7 & 2.8 & تحقق عناصر التصميه في ( الشكل - \\
\hline 2.6 & 2.7 & 2.9 & 2.5 & 2.9 & 2.4 & 2.9 & 2.3 & 2.8 & 2.5 & 2.7 & 2.6 & 2.7 & 2.9 & 2.4 & 2.4 & 2.7 & 2.4 & 2.5 & 2.8 & الاستلام من الفز الرقمى التجريدى \\
\hline 2.8 & 2.8 & 2.9 & 2.5 & 2.9 & 2.9 & 2.9 & 2.4 & 2.6 & 2.7 & 2.6 & 2.8 & 2.7 & 3 & 2.7 & 2.3 & 2.6 & 2.2 & 2.7 & 2.7 & تحقق الحداثة المعاصرة من خلال \\
\hline 2.9 & 2.5 & 2.8 & 2.7 & 3 & 2.9 & 2.8 & 2.7 & 3 & 2.4 & 2.6 & 2.4 & 2.8 & 2.8 & 2.7 & 2.8 & 2.6 & 2.6 & 2.4 & 2.3 & تحقق النسبة والتناسب بين مساحة \\
\hline 2.6 & 3 & 2.9 & 2.6 & 2.7 & 2.5 & 2.9 & 2.7 & 2.3 & 2.5 & 2.4 & 2.6 & 2.7 & 3 & 2.4 & 2.8 & 2.8 & 2.4 & 2.5 & 2.9 & تحقق التوازن بين الوحدة الزخرفية \\
\hline 3 & 2.5 & 3 & 2.5 & 2.6 & 2.6 & 2.8 & 2.7 & 2.8 & 2.6 & 2.8 & 2.8 & 3 & 2.8 & 2.5 & 2.5 & 2.6 & 2.4 & 2.6 & 2.2 & تكامل المظهر العام للتصيم المقترح \\
\hline 16.5 & 16.1 & 17.5 & 15.7 & 17.1 & 16.2 & 17.2 & 15.7 & 16.3 & 15.3 & 15.8 & 16.1 & 16.7 & 17.4 & 15.6 & 15.2 & 15.7 & 14.6 & 15.4 & 15.7 & متوسطات تقييمات المحكمين (ككل) \\
\hline 91.6 & 89.4 & 97.2 & 87.2 & 95.0 & 90.0 & 95.5 & 87.2 & 90.5 & 85.0 & 87.7 & 89.4 & 92.7 & 96.6 & 86.6 & 84.4 & 87.2 & 81.1 & 85.5 & 87.2 & تقيييم الجودة \\
\hline 6 & 9 & 1 & 12 & 4 & 8 & 3 & 15 & 7 & 18 & 11 & 10 & 5 & 2 & 16 & 19 & 14 & 20 & 17 & 13 & الترتيب \\
\hline
\end{tabular}


تشير نتائج جدول (r) إلى أن التصميمات المقترحة من الرؤية الإبداعية للفنون الرقمية

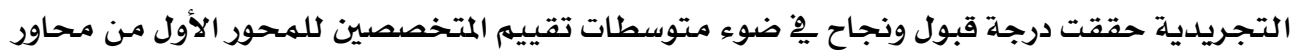

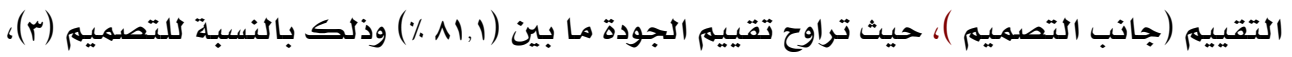

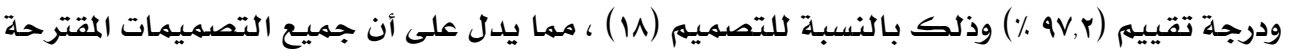

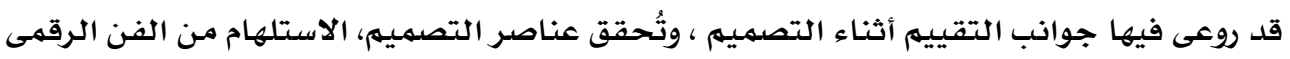

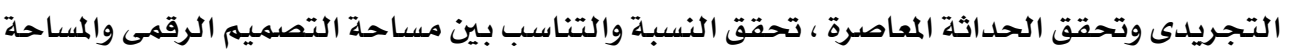

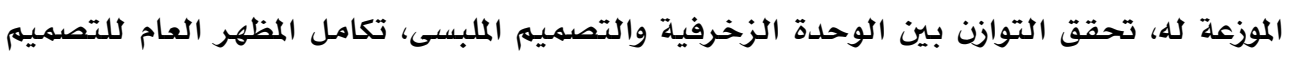
المقترح. الفرض الثانى:

تُحقق التصميمات المقترحة من الروية الإبداعية للفنون الرقمية التجريدية درجة قبول

$$
\text { ونجاح حِ ضوء متوسطات تقييم المتخصصين للجانب الجمالي. }
$$

جلول (r) يوضح متوسطات تقييمات المتخصصين للحانب الحمالى للتصميمات المتترحة

\begin{tabular}{|c|c|c|c|c|c|c|c|c|c|c|c|c|c|c|c|c|c|c|c|c|}
\hline 20 & 19 & 18 & 17 & 16 & 15 & 14 & 13 & 12 & 11 & 10 & 9 & 8 & 7 & 6 & 5 & 4 & 3 & 2 & 1 & عبارة الاستبيان/ التصميه | \\
\hline 2.7 & 2.5 & 3 & 2.6 & 2.9 & 2.8 & 2.8 & 2.8 & 2.4 & 2.3 & 2.7 & 2.7 & 2.4 & 2.9 & 2.3 & 2.4 & 2.9 & 2.8 & 2.7 & 2.8 & تالإبتكار بالاختيار من الفز التجديل \\
\hline 2.2 & 2.6 & 2.9 & 2.7 & 2.9 & 2.9 & 2.9 & 2.5 & 2.4 & 2.4 & 2.9 & 2.5 & 2.6 & 3 & 2.7 & 2.7 & 2.9 & 2.5 & 2.6 & 2.7 & توزيع التصميم الرقىى \\
\hline 2.9 & 2.7 & 3 & 2.5 & 2.9 & 2.5 & 2.9 & 2.8 & 2.4 & 2.6 & 2.5 & 2.7 & 2.7 & 2.9 & 2.9 & 2.2 & 2.8 & 2.8 & 2.9 & 2.6 & الرقافى مع ألوان أزوان التصميه \\
\hline 2.7 & 2.7 & 2.9 & 2.7 & 2.9 & 2.9 & 2.8 & 2.4 & 2.6 & 2.8 & 2.5 & 2.7 & 2.6 & 3 & 2.8 & 2.7 & 3 & 2.6 & 2.6 & 2.7 & تحقق جانب التميز والتنوع \\
\hline 2.7 & 2.6 & 3 & 2.6 & 2.8 & 2.9 & 2.9 & 2.6 & 2.3 & 2.4 & 2.5 & 2.5 & 2.5 & 3 & 2.5 & 2.6 & 2.9 & 2.6 & 2.8 & 2.8 & تطوائمة التصميه المقترح مع \\
\hline 2.6 & 2.6 & 2.9 & 2.7 & 2.9 & 2.6 & 2.8 & 2.4 & 2.4 & 2.5 & 2.4 & 2.4 & 2.2 & 2.8 & 2.6 & 2.5 & 2.8 & 2.6 & 2.7 & 2.6 & |حتواء التصميه علي قيه \\
\hline 15.8 & 15.7 & 17.7 & 15.8 & 17.3 & 16.6 & 17.1 & 15.5 & 14.5 & 15 & 15.5 & 15.5 & 15 & 17.6 & 15.8 & 15.1 & 17.3 & 15.9 & 16.3 & 16.2 & متوسطات تقييمات المحكمين \\
\hline 87.7 & 87.2 & 98.3 & 87.7 & 96.1 & 92.2 & 95.0 & 86.1 & 80.5 & 83.3 & 86.1 & 86.1 & 83.3 & 97.7 & 87.7 & 83.8 & 96.1 & 88.3 & 90.5 & 90.0 & تقيييم الجودة \\
\hline 10 & 13 & 1 & 11 & 3 & 6 & 5 & 16 & 20 & 18 & 15 & 14 & 17 & 2 & 12 & 19 & 4 & 9 & 7 & 8 & الترتيب \\
\hline
\end{tabular}


تشير نتائج جدول (r) إلى أن التصميمات المقترحة من الرؤية الإبداعية للفنون الرقمية

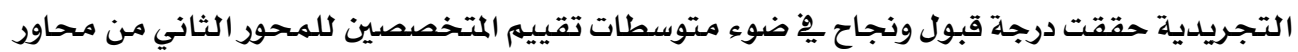

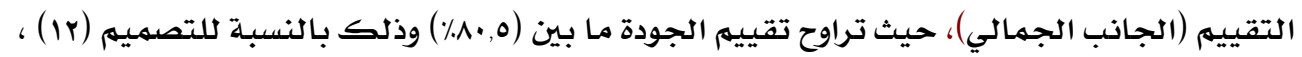

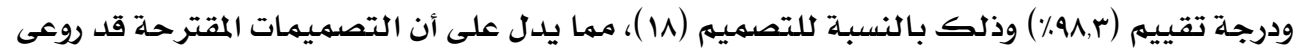

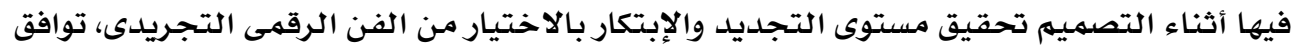

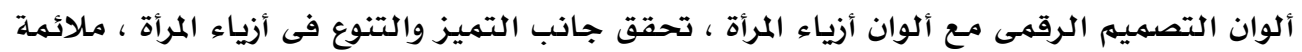

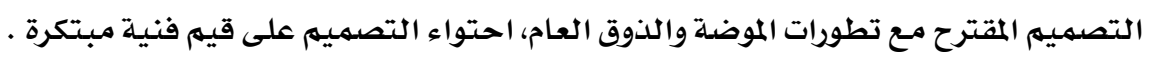
الفرض الثالث:

تُوجد علاقة ذات دلالة إحصائية بين الجانب الجمالى والجانب التصميمى بالتصميمات

$$
\text { المقترحة من الفن الرقمى التجريدى }
$$

جدول ( ع ) يوضح حساب معامل ارتباط الرتب لسبيرمان بين تقييمات المحكمين للتصميمات المقترحة من جانب

التصميم والجانب الجمالي من الرؤية الإبباعية للفنون الرقمية التجريدية

\begin{tabular}{|c|c|c|}
\hline الجانب الجمالي & جانب التصميي & \\
\hline$*_{,, 0 \xi}$ & 1 & جانب التصميم \\
\hline 1 & $*_{,, 0 \varepsilon}$ & الجانب الجمالي \\
\hline
\end{tabular}

وتشير نتائج جدول ( ع) إلي أن قيمة معامل ارتباط الرتب لسبيرمان (ر= ؟ه.. ) وهى دالة

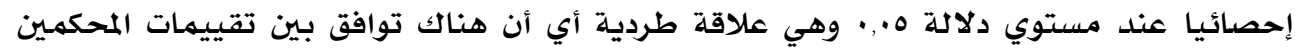

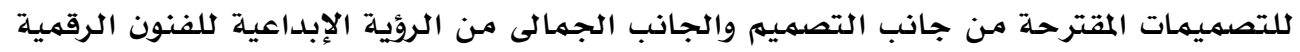
التجريدية.

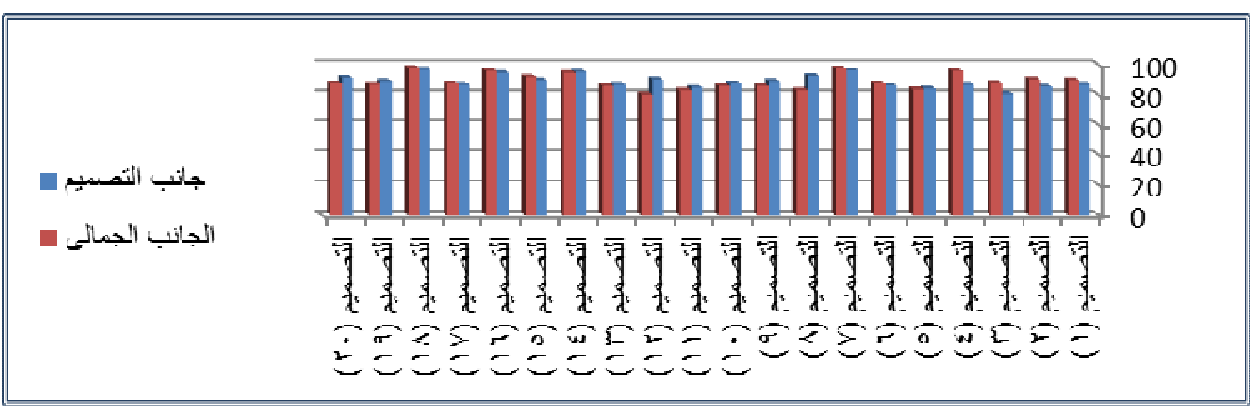

شكل ( ) يوضح العلاقة بين جانب التصميم والجانب الجمالى فى تقييمات المحمكين 


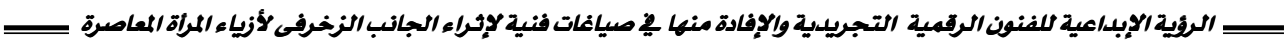

الفرض الرابع :

يُوجد فرق دال إحصائيا عند مستوى دلالة ه •., بـين متوسطات التصميمات المقترحسة مـن

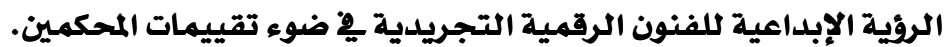

One- way وللتحقق من صحة هذا الفرض تم حساب تحليل الأحادي ِِّ اتجاه

ANOVA

One- way ANOVA جدول ( ) نتائج تحليل التباين الأحادي يِّ اتجاه

لتقييمات المحكمين للتصميمات المقترحة من الرؤية الإبداعية للفنون الرقمية التحريلية

\begin{tabular}{|c|c|c|c|c|c|}
\hline مستوي & قلليمة قللّة & متوسط & الدرجات & مجموع المربعات & مصلدر التباين \\
\hline \multirow{3}{*}{.004} & \multirow{3}{*}{3.490} & 1.136 & 19 & 21.585 & التباين بين المجموعات \\
\hline & & .326 & 20 & 6.510 & التباين داخل المجموعات \\
\hline & & & 39 & 28.095 & التباين الكلي \\
\hline
\end{tabular}

يتضح من جدول ( ) وجود فرق دال إحصائيا عند مستوي ه.. · بـين متوسطات تقييمات

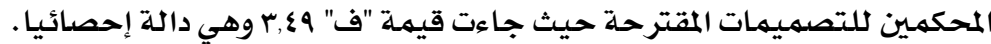

المثربطن
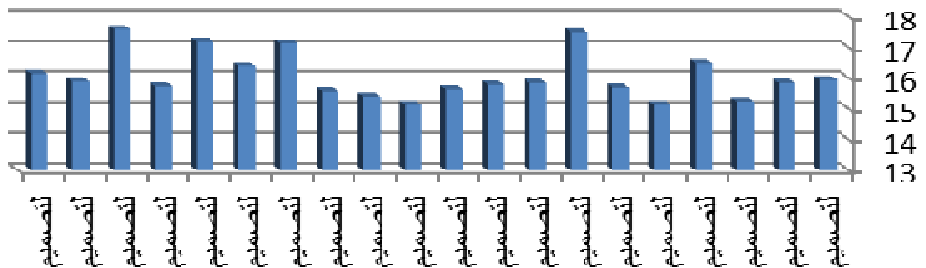

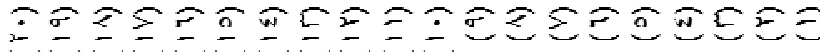

شكل (r) متوسطات تقييمات المحكمين للتصميمات المقترحة 
مجلة بحوث التربية النوعية - عدد VV - يوليو r.lV

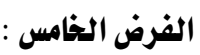

تُحقق التصميمات المقترحة من الرؤية الإبداعية للفنون الرقمية التجريدية درجة قبول ونجاح بِ ضوء متوسطات تقييم السيدات.

جدول (7) متوسطات تقييمات السيدات للتصميمات المقترحة

\begin{tabular}{|c|c|c|c|c|c|c|c|c|c|c|c|c|c|c|c|c|c|c|c|c|}
\hline 20 & 19 & 18 & 17 & 16 & 15 & 14 & 13 & 12 & 11 & 10 & 9 & 8 & 7 & 6 & 5 & 4 & 3 & 2 & 1 & عبارة الاستبيان/ التصميم \\
\hline 2.6 & 2.4 & 2.9 & 2.5 & 2.8 & 2.7 & 2.7 & 2.3 & 2.7 & 2.3 & 2.6 & 2.6 & 2.3 & 2.8 & 2.2 & 2.2 & 2.8 & 2.7 & 2.6 & 2.7 & الرقمى يتناسب مع أزياء \\
\hline 2.2 & 2.6 & 2.9 & 2.7 & 2.9 & 2.9 & 2.9 & 2.4 & 2.5 & 2.7 & 2.9 & 2.5 & 2.6 & 3 & 2.7 & 2.4 & 2.9 & 2.5 & 2.6 & 2.7 & ملائمة التصميه المترح مع \\
\hline 2.9 & 2.7 & 3 & 2.5 & 2.9 & 2.5 & 2.9 & 2.4 & 2.8 & 2.2 & 2.5 & 2.7 & 2.7 & 2.9 & 2.9 & 2.6 & 2.8 & 2.8 & 2.9 & 2.6 & | فتواء التصمييم علي قييم \\
\hline 2.7 & 2.7 & 2.9 & 2.7 & 2.9 & 2.9 & 2.8 & 2.6 & 2.4 & 2.7 & 2.5 & 2.7 & 2.6 & 3 & 2.8 & 2.8 & 3 & 2.6 & 2.6 & 2.7 & ملتى الإقبال على ارتداء \\
\hline 2.7 & 2.6 & 3 & 2.6 & 2.8 & 2.9 & 2.9 & 2.3 & 2.6 & 2.6 & 2.5 & 2.5 & 2.5 & 3 & 2.5 & 2.4 & 2.9 & 2.6 & 2.8 & 2.8 & | توزيع الوحدة الزخرفية \\
\hline 2.6 & 2.6 & 2.9 & 2.7 & 2.9 & 2.6 & 2.8 & 2.4 & 2.4 & 2.5 & 2.4 & 2.4 & 2.2 & 2.8 & 2.6 & 2.5 & 2.8 & 2.6 & 2.7 & 2.6 & 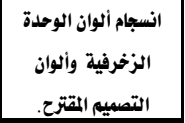 \\
\hline 2.6 & 2.6 & 3 & 2.9 & 3 & 2.9 & 2.9 & 2.8 & 2.9 & 2.4 & 2.7 & 2.9 & 2.8 & 2.9 & 2.9 & 2.6 & 2.4 & 2.6 & 2.7 & 2.8 & مناسبة توزيع التصميم \\
\hline 2.6 & 2.7 & 2.9 & 2.5 & 2.9 & 2.4 & 2.9 & 2.8 & 2.3 & 2.4 & 2.7 & 2.6 & 2.7 & 2.9 & 2.4 & 2.5 & 2.7 & 2.4 & 2.5 & 2.8 & مستوى الابتكار والتجديد \\
\hline 2.8 & 2.8 & 2.9 & 2.5 & 2.9 & 2.9 & 2.9 & 2.6 & 2.4 & 2.3 & 2.6 & 2.8 & 2.7 & 3 & 2.7 & 2.7 & 2.6 & 2.2 & 2.7 & 2.7 & والتنوع فى أزياء المرأة. \\
\hline 2.9 & 2.5 & 2.8 & 2.7 & 3 & 2.9 & 2.8 & 3 & 2.7 & 2.8 & 2.6 & 2.4 & 2.8 & 2.8 & 2.7 & 2.4 & 2.6 & 2.6 & 2.4 & 2.3 & 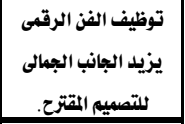 \\
\hline 2.6 & 3 & 2.9 & 2.6 & 2.7 & 2.5 & 2.9 & 2.3 & 2.7 & 2.8 & 2.4 & 2.6 & 2.7 & 3 & 2.4 & 2.5 & 2.8 & 2.4 & 2.5 & 2.9 & جودة التصميم وتكامله. \\
\hline 3 & 2.5 & 3 & 2.5 & 2.6 & 2.6 & 2.8 & 2.8 & 2.7 & 2.5 & 2.8 & 2.8 & 3 & 2.8 & 2.5 & 2.6 & 2.6 & 2.4 & 2.6 & 2.2 & تحقق درجة جودة فى الرقيار التصميمات \\
\hline 32.2 & 31.7 & 35.1 & 31.4 & 34.3 & 32.7 & 34.2 & 30.7 & 31.1 & 30.2 & 31.2 & 31.5 & 31.6 & 34.9 & 31.3 & 30.2 & 32.9 & 30.4 & 31.6 & 31.8 & متوسطات تقييمات \\
\hline 89.4 & 88.0 & 97.5 & 87.2 & 95.2 & 90.8 & 95.0 & 85.2 & 86.3 & 83.8 & 86.6 & 87.5 & 87.7 & 96.9 & 86.9 & 83.8 & 91.9 & 84.4 & 87.7 & 88.3 & تقييي الجودة \\
\hline 7 & 9 & 1 & 13 & 3 & 6 & 4 & 17 & 16 & 19 & 15 & 12 & 10 & 2 & 14 & 20 & 5 & 18 & 11 & 8 & الترتيب \\
\hline
\end{tabular}


تشير نتائج جدول (ج) إلى أن التصميمات المستحدثة من الرؤية الإبداعية للفنون الرقمية

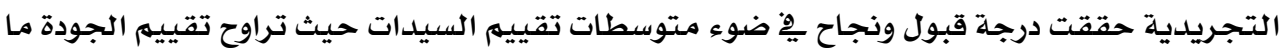

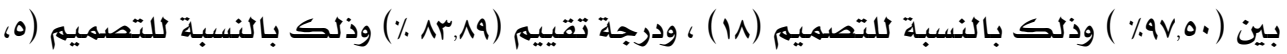

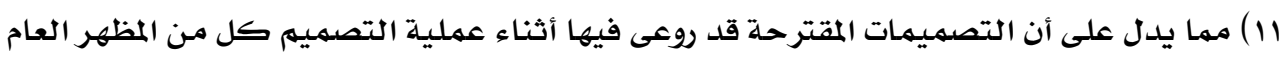

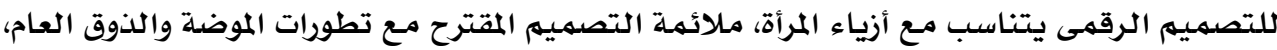

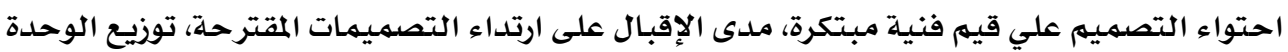

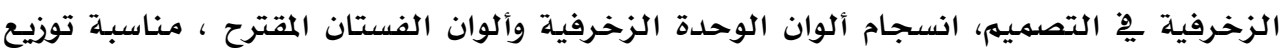

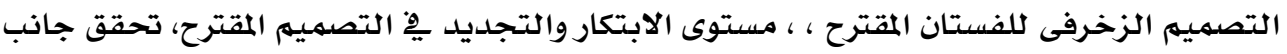

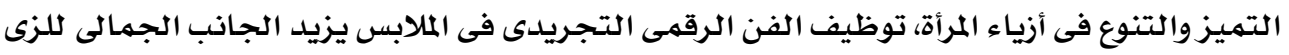

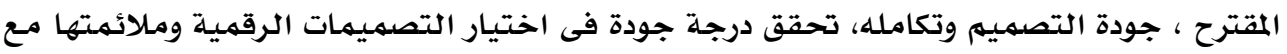

أزياء المرأة.

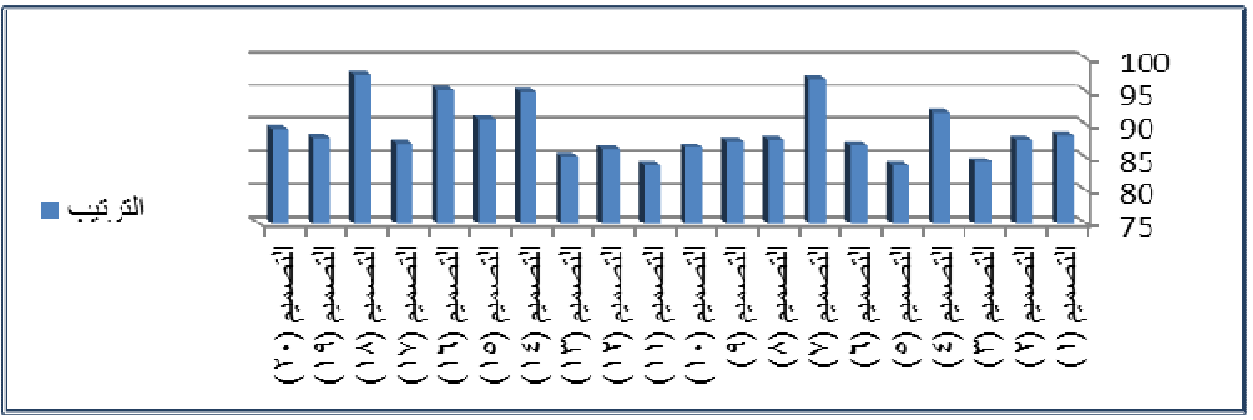

شكل (r) متوسطات تقييمات السيدات للتصميمات المقترحة

الخلاصة :

ا. تحقق من خلال اقتراح تصميمات ملبسية للمرأة فرصدة الإبتكار والتحرر من التصميمات

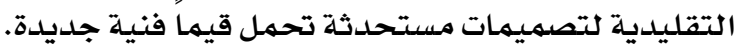

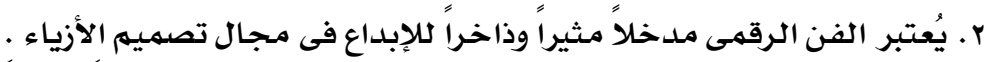

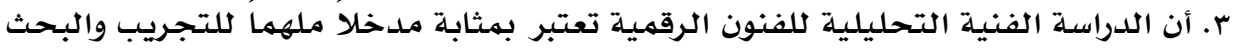

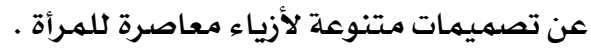

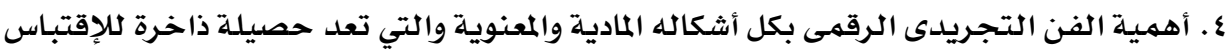
منها ه. إمكانية ابتكار تصميمات لأزياء المرأة بأساليب متنوعة وتقنيات مختلفة من حيث اللون

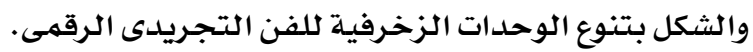
التتوصيات : ا . ضرورة البحث والتجريب فى الفنون بصفة عامـة والفنون الحديثة بصفة خاصدة كمحاولة

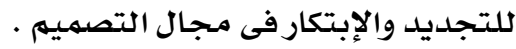


مجلة بحوث التربية النوعية - علدد

r. أهمية الثقافة الفنية فى إثراء الذوق الفنى الملبسى والرؤية الفنية والإبداعية له.

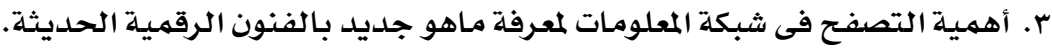

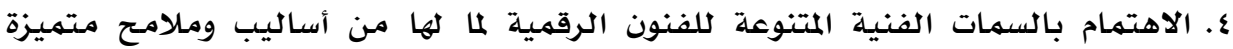

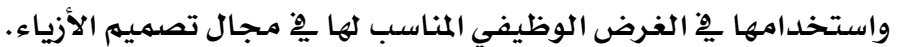

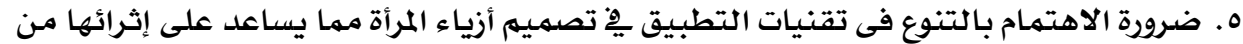
الناحية الجمالية والوظيفية .

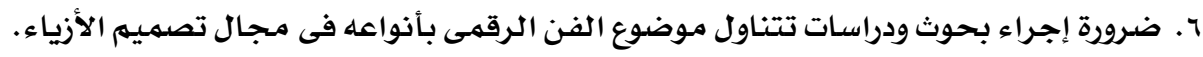
المراجع والمسادر العلميهة:

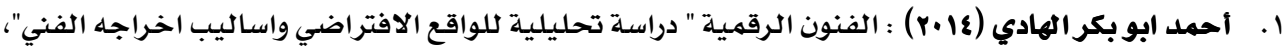

رسالة دكتوراه غير منشورة ، كلية الفنون الجميلة والتطبيقية ، جامعة السودان للعلوم والتكنولوجيا.

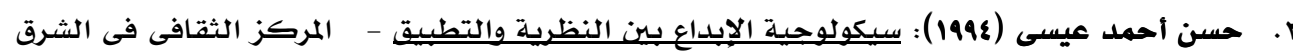
الأوسط - مكتبة الإسراء.

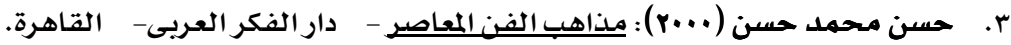

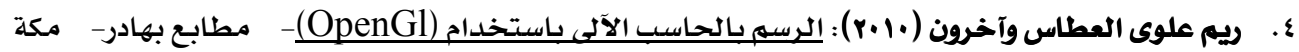
المكرمة - السعودية.

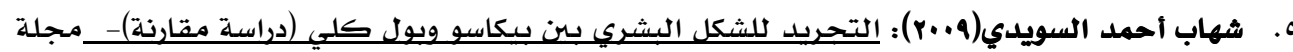

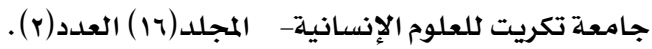

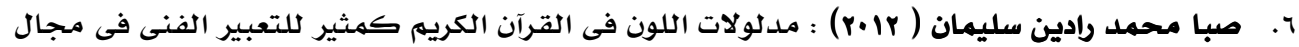

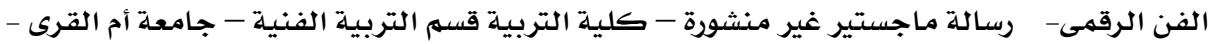
السعودية.

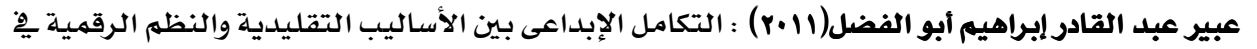

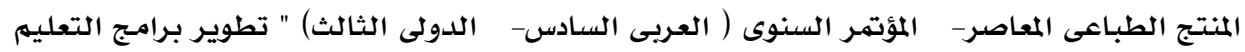

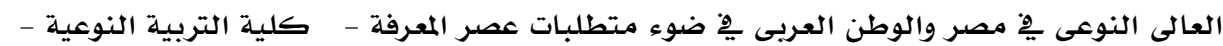
جامعة المنصورة. ^. عفيفى بهنسى(1941) : تاريخ الفنوالعمارة - جامعة دمشق- مطبعة خالد بن الوليد - سوريا.

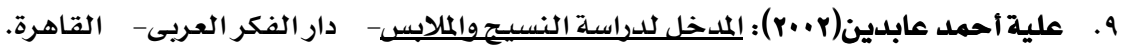

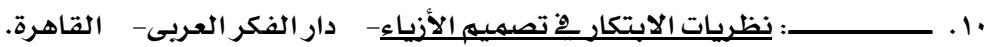

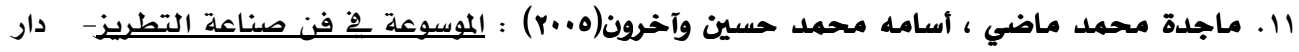
المصطفى للطباعة والترجمة - بنها.

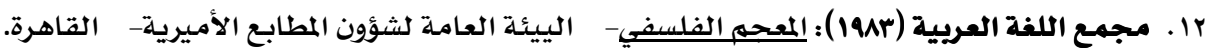

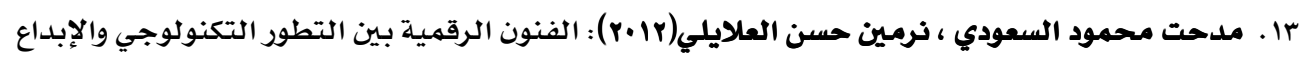

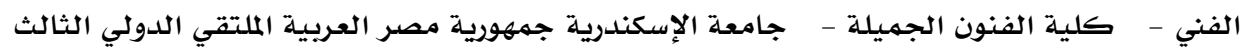
للفنون التشكليلية (حوار جنوب- جنوب) بعنوان "الفنون التشكيلية والمتغيرات العالمية" . 
בب الرؤية الإبباعية للفنون الرقمية التجريدية والإفادة منها ِِ صياغات فنية لإخراء الجانب الزخرفى لأزياء المراة المعاصرة لـ عا. مروة ممدوح مصطفى حمود (Y|•r): التكامل الإبداعى بين أساليب النظم الرقمية الحديثة ومعرفة مصمهم الملابس المطبوعة، المؤتتـر السنوى ( العربى السـابع- الدولى الرابع) " إدارة المعرفة وإدارة رأس المال الفكرى فى مؤسسات التعليهم العالى فى مصر والوطن العربى - كلية التربية النوعية - جامعة المنصورة.

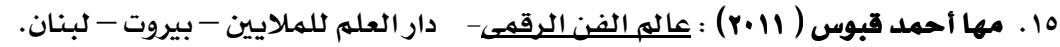

17 . نجاة محمد باوزير(1941) : فن تصميهم الأزيـياء- طا- دار الفكر العربي- القاهرة . IV . نعمت إسماعيل علام (1994) ) فنون الغرب فِ العصور الحديثة - دار المعارف - القاهرة.

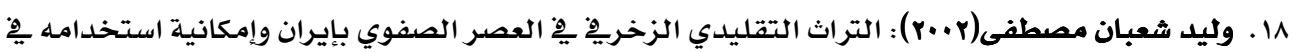
إثراء المفروشات- رسالة دكتوراه غير منشورة - كلية الاقتصاد المنزلي - جامعة حلوان.

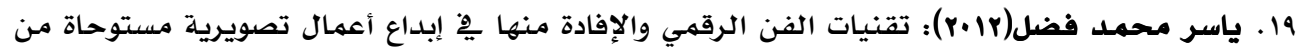
التعبيرات الروحية للفن الشعبي- الملتقي الدولي الثاني للفنون التشكيلية (حوار جنوب- جنوب)بعنوان الفنون التشكيلية والمتغيرات العالمية - جامعة أسيوط.

20. John M. Turnpennt (1981): Fashion and illustration, London.

21. Ross, T (1994): The Art of Arabian Costume-(4.ed) -California: EPS $\backslash$ Players Press.

22. http://almadapaper.net

23. http://al-bassit.blogspot.com

24. http://ar.wikipedia.org

25. http://fac.ksu.edu.sa

26. http://www.imgrum.net

27. http://jazarah.net

28. http://webdesignerwall.com

29. http://www.aun.edu.eg

30. http://www.w-enter.com

31. http://www.startimes.com 
Benefiting of Creative Vision of Digital Arts abstract in formulating arts to Enrich Decorative side for modern women's fashion costume

\section{Abstract}

Digital Technology became the language of this age, data is introduced to digital system of computers then converted to technical designs that can be used in designing costumes, the study aimed at clarifying the beauty of digital art and benefit of it in creating new modern women's fashion design that are unique, to find contemporary solutions through experimentation in art digital abstract and draw new approaches to the employment of designs based on the philosophy of digital abstract art , to achieve the aesthetic aspect of design for women's fashion ، The results showed that the designs implemented of digital abstract art achieved a degree of acceptance and success in the light of the of specialists assess c from both design and aesthetic beauty view of point a and there is a statistical value of significant relationship between the aesthetic aspect and the proposed digital abstract art designs, there is a statistical significant difference at 0.05 level between the means of executing the designs of the creative vision of digital abstract art in the light of the evaluations of the judges, and the implemented designs of digital abstract art achieved a degree of acceptance and success in the light of the evaluation of the women's point of view. 


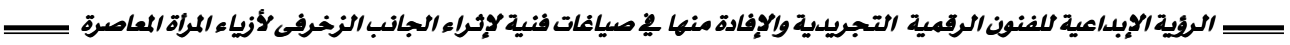

هلمق (1) استمهارة استبيان للاتصميسمات الاقتزحة ( السادة المكمينين)

\begin{tabular}{|c|c|c|c|c|}
\hline غير ملائم - ائ & ملائم لحد ما & ملائم & 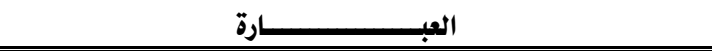 & ค \\
\hline \multicolumn{5}{|c|}{ أولا : جانب التصميه } \\
\hline & & & تحقق عناصر التصميه في ( الشكل - الخط - اللون - اللساحة ) . & 1 \\
\hline & & & الاستلهام من الفن الرقمى التجريلدى والتأكيد على الحداثة فى التصميه. & $r$ \\
\hline & & & تحقق الحداثة المعاصرة من خلال التوظيف على ملابس المرأة. & $r$ \\
\hline & & & تحقق النسبة والتناسب بين مساحة التصميم الرقهى والمساحة الموزعةله. & $\varepsilon$ \\
\hline & & & تحقق التوازن بين الوحدة الزخرفية والتصميه الملبسى & 0 \\
\hline & & & تكامل المظهر العام للتصميم المقترح المقترحة. & 9 \\
\hline \multicolumn{5}{|c|}{ 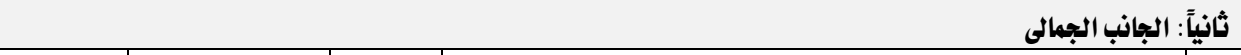 } \\
\hline & & & تحقيق مستوى التجديد والإبتكار بالاختيار من الفز الرقمى التجريلى . & 1 \\
\hline & & & توزيع التصميم الرقعى فى أزياء المرأة. & r \\
\hline & & & توافق ألوان التصميم الرقمى مع ألوان أزياء المرأة & r \\
\hline & & & تحقق جانب التميز والتنوع فى أزياء المرأة . & $\varepsilon$ \\
\hline & & & ملائمة التصميم المقترح مع تطورات الموضة والذوق العام. & 0 \\
\hline & & & احتواء التصميه علي قيم فنية مبتكرة & 1 \\
\hline
\end{tabular}

همق (ץ) استهمارة استبيان للتصميسمات الاقتزحة (عينة البمث)

\begin{tabular}{|c|c|c|c|c|}
\hline غير ملائم & ملائم لحد ما & ملائم & 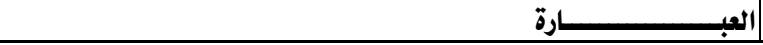 & a \\
\hline & & & |المظهر العام للتصميم الرقهى يتناسب مع أزياء المرأة. & 1 \\
\hline & & & |ملائمة التصميه المقترح مع تطورات الموضة والذوق العام. & $r$ \\
\hline & & & |حتواء التصميم علي قيم فنية مبتكرة & $r$ \\
\hline & & & ملدى الإقبال على ارتداء التصميمات المقترحة. & $\varepsilon$ \\
\hline & & & توزيع الوحدة الزخرفية في التصميم & 0 \\
\hline & & & |انسجام ألوان الوحدة الزخرفية وألوان الفستان المقترح. & 9 \\
\hline & & & مناسبة توزيع التصميم الزخرفى للفستان المقترح. & $\checkmark$ \\
\hline & & & |مستوى الابتكار والتجديد في التصميي المقترح. & $\wedge$ \\
\hline & & & |تحقق جانب التميز والتنوع فى أزياء المرأة. & 9 \\
\hline & & & توظيف الفن الرقمى التجريلدى فى الملابس يزيلد الجانب الجمالى للزى المقترح. & 1. \\
\hline & & & |جودة التصمييم وتكامله. & 11 \\
\hline & & & تحقق درجة جودة فى اختيار التصميمات الرقمية وملائمتها مع أزياء المرأة. & ir \\
\hline
\end{tabular}

